\title{
Estimation and prediction of the oscillation pattern of meandering geometry in a sub-catchment basin of Bhagirathi-Hooghly river, West Bengal, India
}

\author{
Arnab Ghosh $^{1}$ (D) Malabika Biswas Roy ${ }^{2}$ D $\cdot$ Pankaj Kumar Roy $^{1}$ (D)
}

Received: 4 April 2020 / Accepted: 28 July 2020 / Published online: 11 August 2020

(c) Springer Nature Switzerland AG 2020

\begin{abstract}
Meandering is the winding curve or bends in a river within the floodplain area. Though it is a natural process, it affects the populace by the resultant effect of lateral migration with bank erosion in the floodplain area. The present sub-catchment basin (Nabadwip-Kalyani stretch) of the Bhagirathi-Hooghly river is a vital lifeline of southern West Bengal, which offers adequate water for irrigation, industrialisation, and human habitation. This region is experiencing a favourable geomorphic change through river bank line changing with bank erosion and sinuous meandering. Illegal sand mining and monsoonal flood enhances the meandering process and triggers the reduction of settlement and cropland. The present study elaborates on the migration tendencies and meandering geometry of this zone and tries to predict the future river centerline position in a sinuous course. The study area is divided into 30 cross-sections, which reveals the increasing trend of lateral migration and erosion behaviour towards the eastward section of this region. The spatial and temporal shifting of river centerline and resultant migration observes and predicts through the migration coefficient approach (Hasegawa in Proceedings of the Hokkaido Branch, Japan Society of Civil Engineering, pp 197-202, 1977; lkeda et al. in J Fluid Mech 112:363-377, 1981. https://doi.org/10.1017/S0022112081000451; Motta et al. in Geomorphology 163-164:10-25, 2012. https://doi.org/10.1016/j.geomorph.2011.06.036) by Arc GIS v 9.3.1. This model indicates the trend of channel width decreasing, with increasing near bank velocity in the crescent of meandering bend in future. The simulated and predicted centerline validates by positive linear relation $\left(\mathrm{R}^{2}\right)$ and lowest RMSE value in few cross-sectional areas. The oscillation character of meander signifies the amount of discharge in the sub-catchment basin. The unpredictable behaviour of the migration shows a rapid change of meandering geometry through the increasing nature of bank erosion possibilities with peak discharge during monsoon. The study predicts future centerline of the meandering channel and the information on river migration, which will contribute to the plan on bank erosion and denote the vulnerable zonation.
\end{abstract}

Keywords Channel geometry · Channel migration · Migration coefficient · Centerline · GIS

\section{Introduction}

Rivers represents a remarkable morphometric landscape over the alluvium floodplain area. The old phrase of the river channel in the floodplain area exhibits the formation of the meander and river meandering process. The study of these meandering processes and its effect in the floodplain area is the main focus of river dynamics. The dynamic nature of the river channel shifts lateral or horizontal in the floodplain area with time. These meandering processes also affect enhanced land-use change and threatened outcome towards riverside biota and ecosystem [1, 2].

$\triangle$ Malabika Biswas Roy, malabikabiswasroy@gmail.com; Arnab Ghosh, arnabghosh996@gmail.com; Pankaj Kumar Roy, pk1roy@yahoo.co.in; pk1roy2014@gmail.com | ${ }^{1}$ School of Water Resources Engineering, Jadavpur University, Kolkata 700032, India. ${ }^{2}$ Women's College, Calcutta, Kshirode Vidyavinode Avenue, Kolkata 700 003, India. 
The freely meandering river has a curved channel, which shifts laterally by erosion in the concave side and deposition as point bar on the convex side. The change in meander bend also alters the planform geometry of floodplain morphology. By the course of flood and its alteration, the curvature extends gradually and effects over morphological changes in the river. The oscillation of the meandering river through lateral migration causes a rapid change in the local area. The sluggish nature of the meandering river in the old stage is also affected by high sedimentation that surrounds the river by point bar formation [3]. Lateral migration throughout the river is controlled by stream power, opposing force, bank height, bend radius, and channel width. These migration rates can vary in spatial, temporal, and also a seasonal basis. The channel plan performs changes on the river course through lateral migration, bank line shifting, down cutting, the vital part from geological, geomorphological, hydrological, and engineering points of view in an alluvial river. The river migration process has a substantial effect on bank erosion, sediment budget, and changing hydrodynamic behaviour in the tropical monsoon area. However, sometimes activities like illegal sand mining, building dams, construction on the river bed, land-use change have accelerated the process of bank line shifting in a river. In the present situation, riverbank erosion is the main resultant factor of river migration for human habitation, living within or along the edge of the floodplain area. However, the prime cause of bank erosion is complex coupled with natural factor and anthropogenic behaviour [4]. Both factors can accelerate the process of bank erosion through river migration and meandering bend. The character of fluctuating discharge is a significant factor for migration. The quantity of discharge is responsible for altering meandering geometry, bend curvature, which hastens the speed of cut-off [5-7]. For accelerating the bank erosion procedure, flow velocity affects the river bank's convex and concave side. Monsoonal flood accelerates the erosion rate through the wet and dry cycle when the discharge amount fluctuates.

Several studies have investigated meandering geometry through channel migration of various rivers in every corner of the world. In the early period, Ptolemy researched the migratory behaviour of river Nile astronomically [8, 9]. Later, Geo-archaeological studies had evidence near Luxor and Memphis for the migration of Nile river $[10,11]$. Channel planform changes in river emphasised through the interplay of various processes in the river, on the intensity of bank erosion and cutting $[12,13]$. The practice of lateral migration has been analysed via the interaction between channel drift and channel development [14], floodplain erosion and accretion [15], meander expansion, and interaction involving output. Hickin [16] and Hickin and Nanson [17] studied the relationship between channel drift and the ratio of the radius of meander-bend curvature to channel width, as an essential index in controlling channel migration. The widening river has a curved channel that changes laterally with point bar formation by erosion and deposition in the convex and concave side $[18,19]$. The planform geometry of floodplain morphology alters frequently. As a result of flooding and its adjustment, the curvature extends slowly, and effects change in the river within [20-23]. Lateral migration throughout the river controlled by stream power, opposing force, bank height, bend radius, and channel width. This migration rate can vary in spatial, temporal, and also a seasonal basis [20, 24-26]. River bend curvature and the channel thickness is an element in determining channel altering process.

However, this meandering analysis is complicated, time-consuming, and next to impossible in an entire floodplain system through the ground survey. As a result, the advancement technique like remote sensing (RS) and geographical information system (GIS) used to estimate and predict the meandering pattern and effect of resultant bank erosion [20, 27-31]. The estimation and prediction of meandering nature can be analysed through various statistical method and model prediction survey. The statistical analysis gives us a clear picture of a particular description of river shifting, which may similar to the actual value, and governmental policy can rely upon it [24,32,33]. In the previous discussions, various 2D models for river migration and prediction have been mentioned. These models are based on character analysis of low sinuosity rivers and variable river basins [34-37]. These models follow the Hasegawa [38] and Ikeda's [39] classic or migration coefficient (MC) approach [40-42]. According to this approach, the movement of a river depends on the near-bank velocity, which establishes a mathematical and proportional relationship with the dimensionless coefficient (calibrated data obtained from the field). River migration has the most significant impact on river banks.

Meandering river's oscillation pattern and the various resulting bends arise the bank erosion problem as a natural process. The MC approach provides a clear idea of the future position of the river, changes in future river bends, and future bank erosion through changes in the river's centerline. However, this model does not give an accurate idea of the nature, characteristics, and types of bank erosion. This model is not considered to be the vital relation between sediment dynamic and hydrodynamic with the lateral shifting of the river. Also, various numerical models (ARIMA, Artificial Neural Network, Auto-regression) are currently being used to discuss river migration [43-45]. 
However, these models are statistical and, in most cases, extremely uncertain. Prediction is significant in the case of a meandering river because the forecast has considerable significance in the future planning of the river. Also, many times river migration is influenced by human intervention, so statistical models cannot measure it.

Moreover, all these mathematical models cannot determine the exact magnitude and direction of the river's lateral shifting. Since the MC model considers the near-bank velocity of the stream, it can mainly predict the future channel of the river. Moreover, the physical parameters of the bank have also been discussed in this model. The MC model is a practical, scientific, and appropriate step for future river position and its centerline prediction.

Bhagirathi-Hooghly River is a distributary channel of River Ganges, flowing from his bifurcation stage Mithipur, Murshidabad district, West Bengal towards Bay of Bengal encompassing Kolkata. This river system is the lifeline of part of West Bengal and supplying irrigation, industrialisation, and human habitation in an enormous scope. From the twentieth century, several studies are created based on meandering of altering course and effect of the dominant variable of fluvial-dynamics prediction, estimation and migration on the Bhagirathi-Hooghly river system [46-55]. Due to the diminishing rate of discharge, the nature of this distributary metamorphosed from braiding to the meandering character with modifications through meandering geometry $[52,53,56,57]$. The previous researcher has also emphasised changes that are the spatial and temporal basis on the meandering loop through release in channel instability and meandering. Individual and the agricultural habituation on the river bank erosion due to flooding, continuously affect riparian area beside the course of the river. In certain moves, the vulnerability increases with loss of habitation of land, cattle and property. It is necessary to calculate the nature of migration and to assessed that the problem for the river hazard zone's development with all stakeholder awareness. This study investigates the character of meandering geometry and river migration by time and with the discharge of the river and forecasts the aspect of changing for the upcoming future.

The migrational behaviour and changing nature of the river in human habitation have analysed throughout the technological progress of remote sensing-based on bank erosion, avulsion, and resultant problem [58-61]. The agricultural and human habituated sub-catchment basin (Nabadwip-Kalyani stretch) in the middle course of the Bhagirathi-Hooghly river is continuously affected by flood and bank erosion. In some stretches, the vulnerability is steadily increasing with loss of land, cattle, and property of exposed habitation. It is necessary to calculate the nature of migration and to assessed that the problem for the river hazard zone's development as the stakeholders aware of it. Earlier, lateral shifting and centerline prediction in a sub-section (Katwa-Mayapur stretch) of the BhagirathiHooghly river have also been discussed. In that case, the LR (Lateral regression) model used as a numerical and statistical model [46]. However, there are lots of uncertainty regarding prediction by the LR model due to unscientific forecast process and procedure. Physical parameters and urban structures have not been taken into account in the LR model. The present discussion assesses river migration, lateral shifting, and centerline prediction and its impact on another sub-section of the Bhagirathi-Hooghly river (Nabadwip-Kalyani stretch). The MC model calibrates by the RVR meander toolbox used in Arc GIS v 9.3.1 and validated by $10-20$ years of simulation and error prediction of the river centerline. This study investigates the oscillation character of meandering geometry and river migration by time and with the discharge of this sub-catchment basin. It also forecasts the position of changing centerline for the upcoming future by MC model.

\section{Materials and methods}

\subsection{Study area}

The selected sub-catchment basin of the middle course of Bhagirathi-Hooghly river is up to $161 \mathrm{~km}$ long from Nabadwip (upstream) to Kalyani (downstream) comprising a portion of Burdwan, Nadia and Hooghly district of

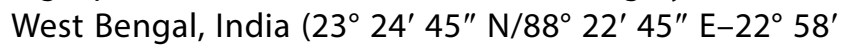
$01^{\prime \prime} \mathrm{N} / 88^{\circ} 24^{\prime} 27^{\prime \prime}$ E). Geologically, this area lies in the Rarh region, the lower portion of the dying deltaic part of the Bengal basin, and composed by a recent deposit of the Pleistocene period. Initially, the area is covered by sandy clay and sand along the course of the river, and fine silt, sandy loam, and loamy soil found in the flat portion of the plain. The entire study area has been divided by a total of 30 cross lines-this cross-line based on the maximum amount of shifting, judging the satellite image from the perspective (Fig. 1).

\subsection{Data used}

This previous data of the study area has prepared through different satellite imageries (LANDSAT III, V, VII, VIIIOLI) for observing migration geometry during 38 years (1980-2018). There is a ten years gap in between data collection of imageries, cause of its availability, and to show the maximum shifting in the region. Based on the images, the furthest extent of shifting observed through time (Table 1). All these images project through Universal Transverse Mercator projection with zone number 45 (UTM 45 N) and World Geodetic System 1984 (WGS 1984) 

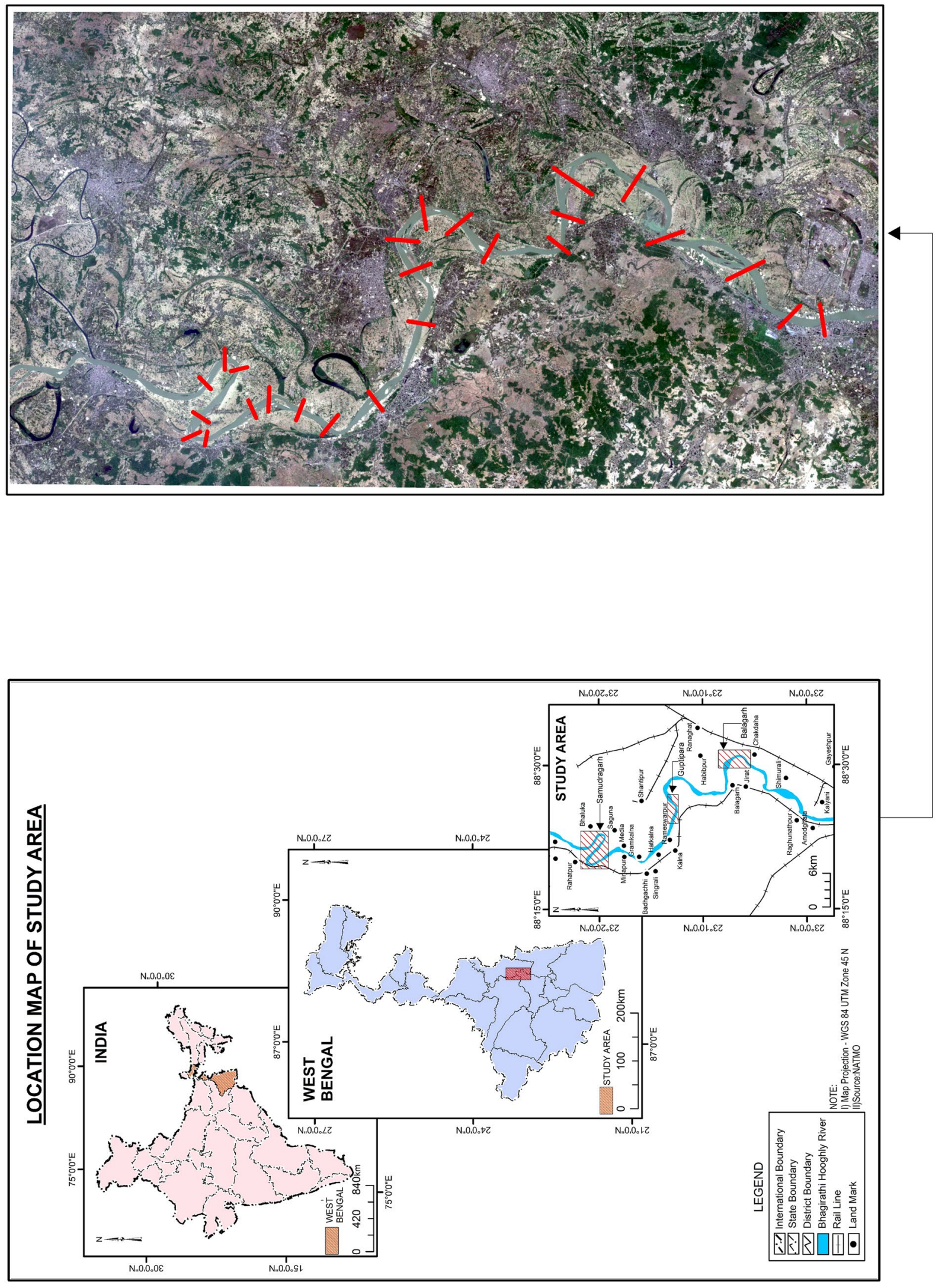

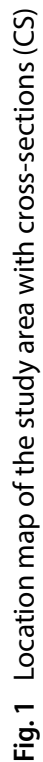


Table 1 Sensor detail of satellite imageries

\begin{tabular}{lllll}
\hline Year & Sensor & Path/row & $\begin{array}{l}\text { Spatial reso- } \\
\text { lution }(\mathrm{m})\end{array}$ & Source of image \\
\hline 1980 & LANDSAT 3 & $138 / 44$ & 60 & USGS Earth Explorer https://www.usgs.gov/ \\
1990 & LANDSAT 5 TM & $138 / 44$ & 30 & USGS Earth Explorer https://www.usgs.gov/ \\
2000 & LANDSAT 7 ETM+ & $138 / 44$ & 30 & USGS Earth Explorer https://www.usgs.gov/ \\
2010 & LANDSAT 8 & $138 / 44$ & 30 & USGS EarthExplorer https://www.usgs.gov/ \\
2018 & LANDSAT 8 OLI & $138 / 44$ & 30 & USGS EarthExplorer https://www.usgs.gov/ \\
\hline
\end{tabular}

datum in Arc-GIS v 9.3.1 software. As the images had retrieved from different sources and not geo rectified for accuracy, a geometric correction introduced with a root mean square error (RMSE) of \pm 0.5 pixels to correct the image to the image registration technique. For the measurement of active channel width, the radius of curvature, channel bend, and channel centerline, 30 cross lines have been assessed over the migrated river course. The length of lateral migration, active channel width, and migration rate has been calculated and predicted through the migration coefficient (MC) approach over these cross-lines. The cross lines have been selected to predict the value that may avail in 2030 and 2040. Then, the present value of the migration rate has been validated with the amount of 2030 and 2040 with an empirical MC approach and error evaluation. Bathymetric survey data for gathering the terrain information on cross-profiles obtained from $A D C P$ (Acoustic doppler current profiler) survey in the river bed. The hydrodynamic data of discharge and velocity of the study period (1980-2018) has been collected from the hydrography division of Kolkata port trust. The Log Pearson type III simulation helps to analyse the discharge of this sub-catchment basin on a seasonal basis.

\subsection{Methodology}

\subsubsection{Meandering character}

The present chart of methodology shows the schematic flow diagram of the whole work in two portions (Fig. 2). The meandering river's morphological analysis calculates through sinuosity index, straight meander and centerline length, erosional and accretional area and length, channel migration, centerline elongation, the radius of curvature, stream power, meandering curve and bend tightness index. The mending geometry of a river depends on the following equation $[62,63]$

$\phi=\omega \sin \frac{s}{M} 2 \pi$
Fig. 2 Schematic diagram of the methodology

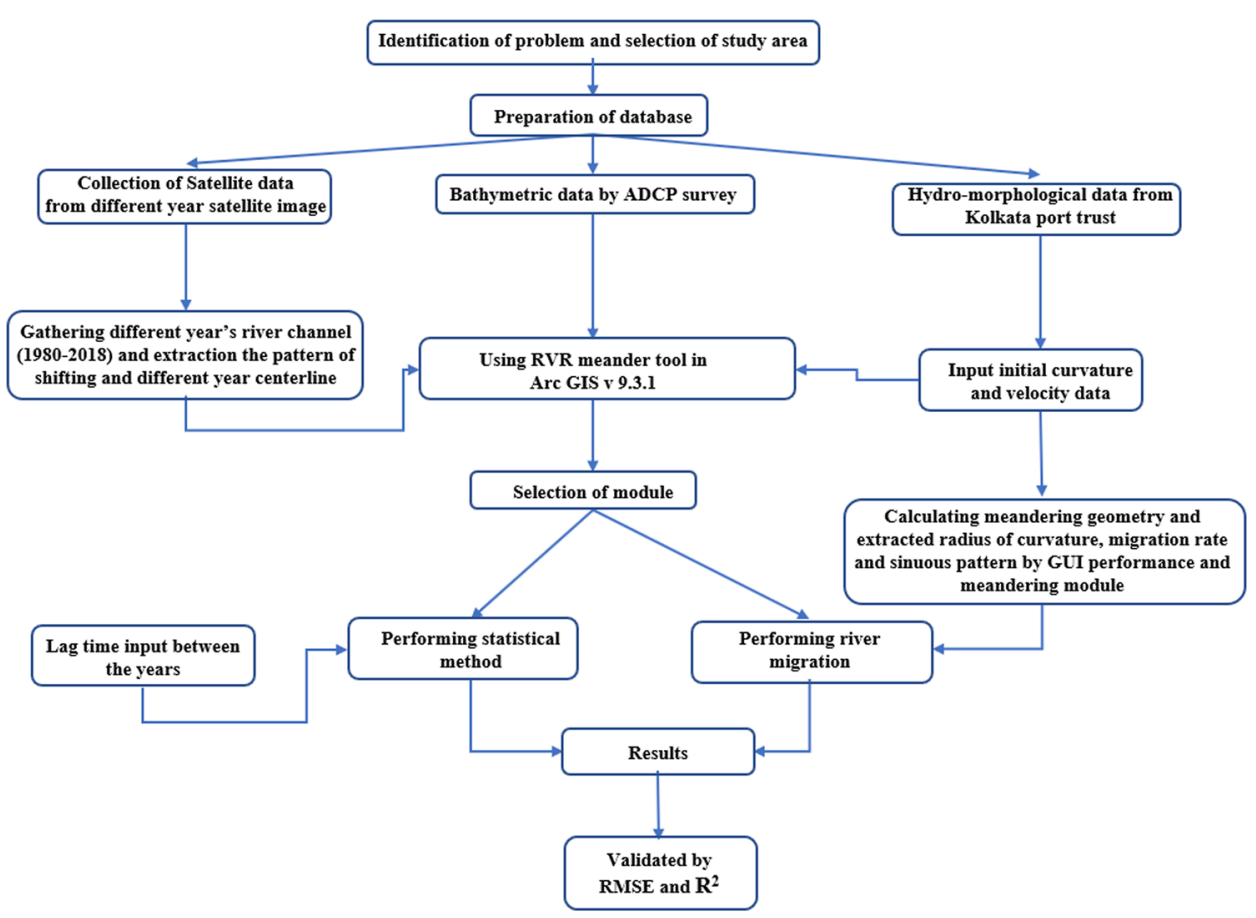


where $\phi$ equals with the direction of location $s, \omega$ is the maximum angle of meander and $M$ is the channel length of the meander. Angle $\phi$ is a unique function based on the disproportionate relationship of meander length. The magnitude of this angle can range from $0^{\circ}$ to $125^{\circ}$, based on which the gooseneck meander formed. The sinuosity index is measured based on the size of this angle. There are several methods for computing the sinuosity index $[32,64]$. In the present study, the sinuosity formula propounded by Muller $[33,64,65]$ has accepted for calculating the value of the meandering loop. The formula is $[64,65]$,

Sinuosity index, $S=\frac{C}{L}$

where $C$ is the channel length, and $L$ is the straight-line valley length/air length between measurement points. Meander Length, Channel Width, Meander amplitude, and radius of curvature are integral to meandering geometry. River migration mainly gave rise to the problem of bank erosion. Riverbank erosion depends entirely on the internal relation between meander length, channel width, and radius of the curvature. Their relationship can be expressed in the following ways [29],

$L=10.9 w^{1.01}=4.7 r_{m}^{0.98}$

where $L$ is the meander length, $w$ is channel width, and $r_{m}$ is the mean radius of curvature. The acute pattern of meandering creates a sine-generated curve-this type of curve based on the sinuosity index and the radius of curvature. Several semi-circular meander amplitudes have been developed, which accelerates the tendency of bank erosion. Although the sine-generated curve has been discussed in various previous discussions, it has not been applied to this river. Although the sine-generated curve does not develop in the current study area, there is a possibility that it will develop in the future. The radius of curvature has a role to play in the formation process of sinecurve. Meander bend's rigidness is quantifying through the radius of curvature. It is an inverse relation with the sinuosity index. The shape is measured via the circle, fitted in winding arc in the bank full channel into the perpendicularly tangent line that bisects meandering point. The radius of curvature measures through $[32,33,66]$,

$R_{c}=\frac{L_{m} K^{1 \cdot 5}}{13(K-1)^{0.5}}$

where $R_{c}$ is the radius of curvature, $L_{m}$ is the wavelength, and $K$ is the channel sinuosity. The radius of curvature is based entirely on field observation and does not require any flow parameters from the river. When the river bend migration is associated with flow velocity, the relationship of channel width with bend curvature $\left(R_{c} / W\right)$ plays a proper initiative to accelerate bank erosion and acute meandering.

\subsubsection{Migration coefficient (MC) approach}

The best way to understand long-term river migration is to use the 2D analytical model based on Hasegawa's [28] and lkeda's [39] migration coefficient approach. The migration coefficient (MC) approach also plays a significant role in lateral migration and predictions in the centerline. The MC approach does not discuss the morpho dynamic and hydrodynamic nature of the river very much but explains the velocity increase of the river, which accelerates curvature. Mainly, the essential factors that control the MC approach in depth average flow velocity in both river bed and transverse side, flow depth, and reach-averaged flow velocity. So, the velocity in the outer bank of river controls channel curvature as well as the channel width of the present condition [40-42],

$(U(s, n), V(s, n), D(s, n))=(1,0,1)+\left(U_{1}(s, n), V_{1}(s, n), D_{1}(s, n)\right)$

where $s$ is streamwise coordinate and $n$ is transverse coordinate, $U$ and $V$ is the depth average flow velocity with particular cross section-wise reach average method $\left(U=U^{*} / U_{c h}^{*}\right.$ and $\left.V=V^{*} / U_{c h}^{*}\right)$ in $s$ and $n$ directions, and $D$ is the flow depth $\left(D=D^{*} / D^{*}{ }_{c h}\right)$ in a particular point in straight or meander channel. Time is the main factor of channel change and curvature deformation in a meandering river. Depending on the depth-average flow velocity and flow depth of the dimensionless coefficient in the MC approach, the long-term river migration and centerline shifting have been accelerated. Also, depending on the average depth flow, bed shear stress, bed elevation in channel curvature, the centerline changes periodically. According to the $M C$ approach, the river bank shifting depends on [40-42],

$\xi^{*}=\frac{\mathrm{d} n_{b}^{*}}{\mathrm{~d} t^{*}}$

where $n_{b}^{*}$ is the transverse coordinate in the outer bank portion of the river with velocity and $t^{*}$ is a specific period. If the channel width has been fixed, then the river centerline's movement depends on the condition of the outer bank. The evolution of the channel centerline from a midpoint portion on the river depends on [40-42],

$\frac{d x_{P}}{d t}=-\xi \sin \theta$
$\frac{d y_{P}}{d t}=+\xi \cos \theta$

where $x_{p}$ and $y_{p}$ have rational relation with half channel width $\left(B^{*}\right)$ in a dimensionless coordinate in any 
Fig. 3 a Active channel width with time. b Profile wise change of width with time
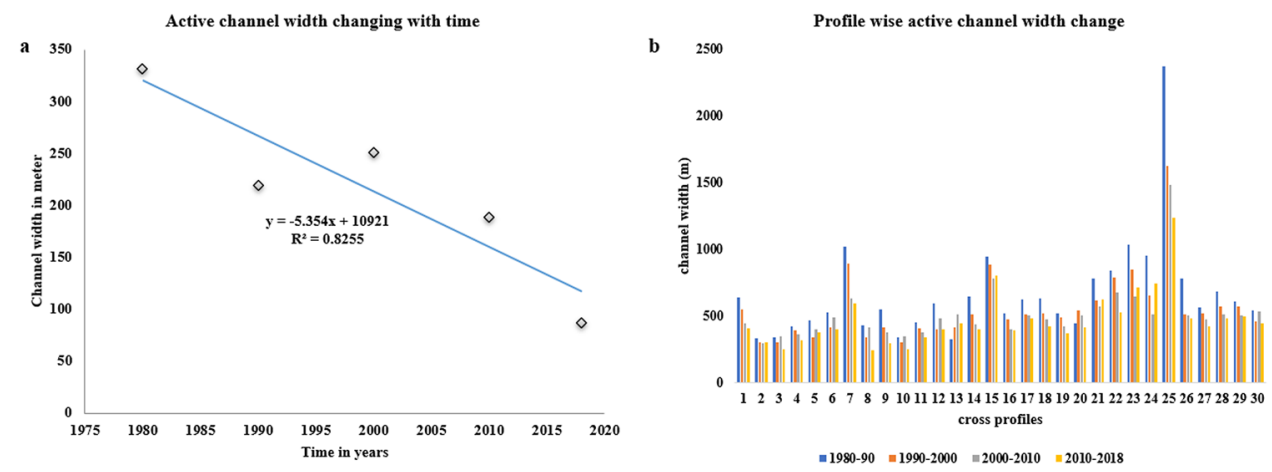

mid-channel portion, time $(\mathrm{t})$ and lateral shifting $(\xi)$ depends on reach average velocity $\left(U_{c h}^{*}\right)$ of every cross-section along the river. It suggests that in the MC approach, river migration depends on the accelerating velocity to the outer river bank and its relationship to the dimensionless coefficient (depth-averaged flow velocity and flow depth). The river's velocity is higher in the external bank of the river, which increases the migration and bank erosion problem in the river [28, 39-42].

$\xi(s)=E_{0} U_{1}(s, n=1)$

where in-stream lateral shifting $\xi(s)$ depends on calibrated erosion coefficient $\left(E_{0}\right)$ with bank soil properties and land use and hydrodynamic behaviour of the flow. However, compared to the different years in the current discussion, the migration of channel centerline with the help of the MC approach is as follows [40-42],

$\left(x_{\text {new }}, y_{\text {new }}\right)=\left(x_{\text {old }}, y_{\text {old }}\right) \frac{B_{\text {old }}^{*}}{B_{\text {new }}^{*}}$

The dimensionless centerline coordinate $(x, y)$ relates and changes with the half widths of the channel in every cross-section. This discussion proves that the channel centerline varies a lot with the channel width. If the channel width can be kept constant, then the variation cannot be understood.

\section{Result and discussion}

\subsection{Channel configuration}

\subsubsection{Active channel width}

The width of the channel represents the cross-sectional variation of the channel and channel change's prime factor [46]. The trend analysis shows that, from 1980 to the present time, the active channel width decreased by up to $55 \%$ (Fig. 3a). It is mainly due to the increase of deposition and change of the flow in the river. The most significant reduction of channel width found in the present time and 1990's scenario, up to $170 \mathrm{~m}$. Mainly in meandering stretches are responsible for this reduction. From decade wise study, it shows the variation through the profiles and the most decrease of channel width found in the 1990-2000 and present era. Through the cross-sectional survey, the active channel width shows decreasing nature on a decadal basis. Maximum spatial and temporal variation in channel width is observed in cross-section (CS) 25 of $2236 \mathrm{~m}$, and the minimum difference has been perceived in CS 2 with $31.1 \mathrm{~m}$. The maximum deviation proves the increasing amount of sedimentation in the river bed with lateral width change. Maximum sediment flux, lower flow velocity, and increasing bank erosion may be the main reason behind the narrowness of the channel from 1980-1990 to 2010-2018. The decreasing trend also affects human habitation in an unscientific way (Fig. 3b).

\subsubsection{Meandering geometry}

Within the study region, this basin also attracts with its meandering course near Nabadwip-Dongarpara reach, and a two folded meandering bend along the path (Fig. 4). This meandering nature of the river extracted and exhibited the past data of this old age river [46]. This bend shows the diminishing kind of radius of curvature, meandering amplitude, and bend width from 1980-2018 (Eq. 1). The meandering curve and meandering amplitude of this area reveal a decreasing nature, but the meandering bend width is slightly higher (Eq. 3). This diminishing trend proves the development of cut off that may prevail shortly. The decadal change also shows that the channel is much erosive in its concave side (Fig. 5). The top layer of the region is alluvium higher proportionately in the sand residue. This type of formation is essential for erosion. Also, the unscientific development of railway bridge in this region on loose soil helps to erode bank by the river. 

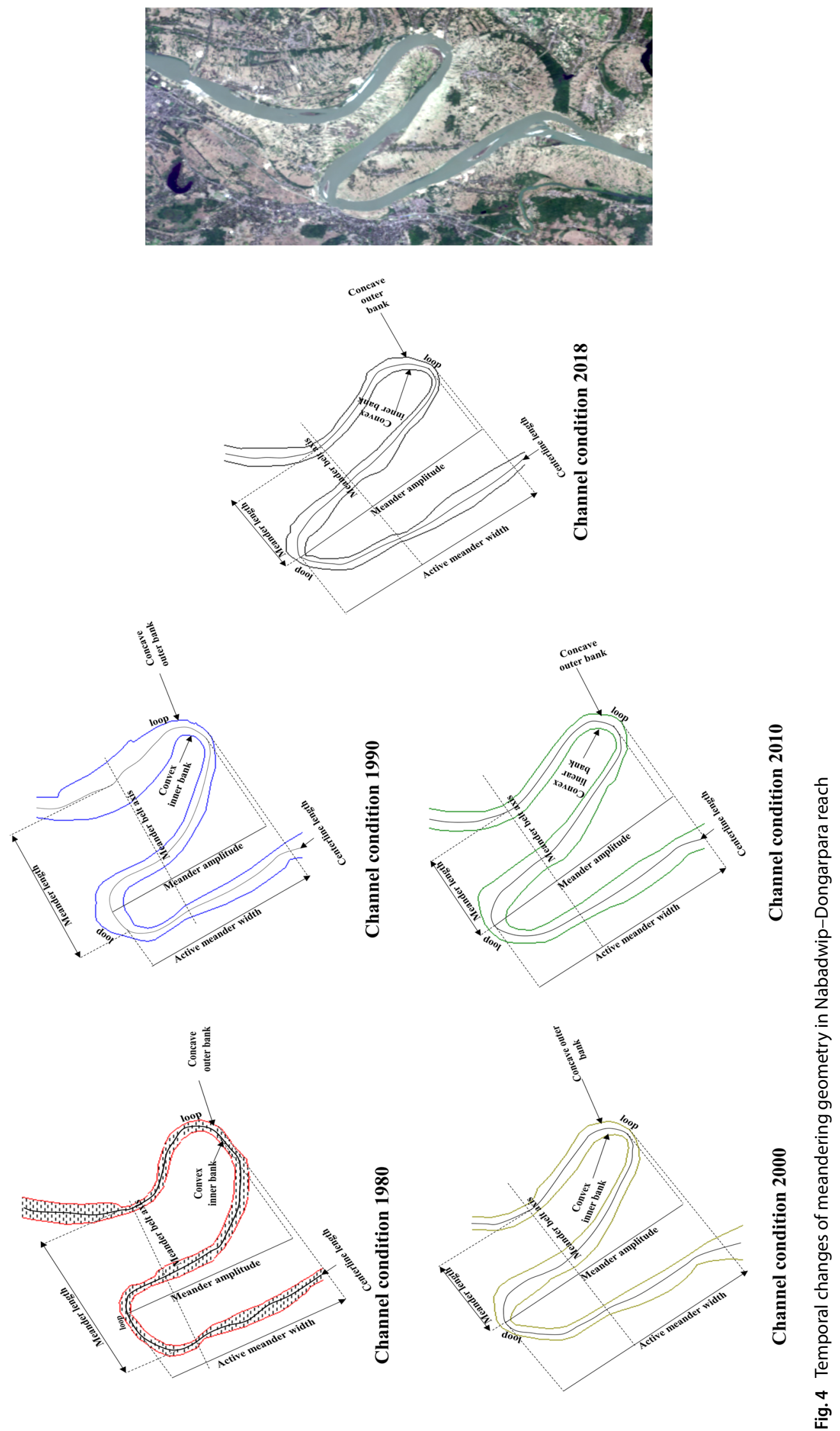

SN Applied Sciences

A SPRINGER NATURE journal 


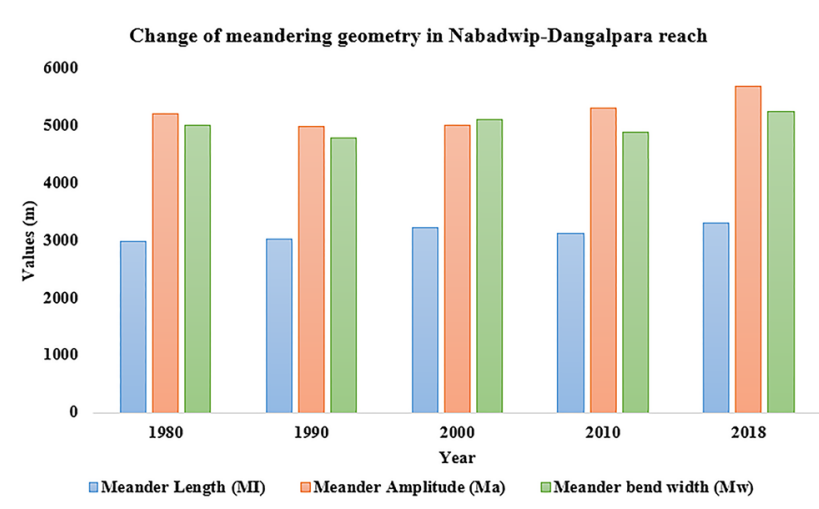

Fig. 5 Temporal changes of meandering geometry using the bar diagram in Nabadwip-Dongarpara reach

\subsubsection{Radius of curvature}

Meander bend's rigidness is quantifying through the radius of curvature [46]. It is an inverse relation with the sinuosity index (Eq. 4). The shape is measured via the circle, fitted in bending arc in the bank full channel into the perpendicularly tangent line that bisects meandering point (Fig. 6). The trend of curvature in all sub-catchment basin changes rapidly from 1980-2018. The changes highly found in 2000, as it is excellent flood time. In the case of active channel width, this time is also a navigable factor for width change. From 2000, the radius of curvature still increases due to the reduction of flow and increased siltation. However, in Nabadwip-Dongarpara reach, the radius of curvature increases from $515 \mathrm{~m}$ in 1980 to $943 \mathrm{~m}$ in 2018, which accelerates the shifting process (Fig. 7). The calculation processes through polynomial data because of the fluctuation of data in time gathering.

\subsubsection{Bend Tightness Index}

BTI (Bend Tightness Index) has measured through the ratio between the radius of curvature $(\mathrm{RC})$ with channel width near meander bend [46]. Meander bends are safe from the down cutting of rivers in lower BTI values. In the Nabadwip-Dongarpara reach, the BTI value increases swiftly from 1.83 in 1980 to 1.98 in 2018 (Fig. 8). The study also depicts a positive relationship between higher BTI values and top bend curvature rates. This fact proves that this area is going through the hazardous rate of river migration.

\subsection{Channel design with Sinuosity Index (SI)}

The polynomial trend of overall sinuosity of the study area increases from 1.7 (1980) to 2.4 (2018). It shows the high amount of siltation and reduction of flow pattern in the study area. The overall sinuosity gradually decreased in 2000-2010 during the flood time (Fig. 9). The polynomial trend is used for the large sets of data and fluctuation happen for gathering them [46]. The general trend of sinuosity index shows the increasing nature of sinuosity value all over the area (Eq. 2). That indicates the expanding nature of meandering and sinuous course and the sharp cut-off may avail in future at Nabadwip-Dongarpara portion (Fig. 10). There are many oxbow lakes and abundant channel throughout the study area, which proves the oscillation character of the river channel from the past. This growing sinuosity also demonstrates the tendency of channel shifting in future, affecting the riverside habitation.

\subsection{Change of channel and meandering geometry with discharge}

The relationship between average annual and annual peak discharge shows a different distribution (Fig. 11). The results of Log-Pearson type III distribution show 2 years $\left(Q_{2}\right), 5$-year $\left(Q_{5}\right)$, 10 years $\left(Q_{10}\right)$, 25-year $\left(Q_{25}\right)$, 50-year $\left(Q_{50}\right)$ and 100-year $\left(Q_{100}\right)$ recurrence interval of discharge which are 18,657, $23,245,37,543,43,567,47,894$, and $51,234 \mathrm{~m}^{3} \mathrm{~s}^{-1}$ respectively. The result shows that flood magnitude is higher in the $\mathrm{Q}_{10}$ and $\mathrm{Q}_{25}$ period rather than other ones. So, a higher amount of shifting occurs between $Q_{10}$ and $Q_{25}$. As we consider, mean annual peak discharge is a primary factor of meandering change, so we try to relate it with other parameters. The result shows that due to the increase of peak discharge, the variables like sinuosity, channel width, channel migration, and radius of curvature rapidly change. The diminishing trend of sinuosity with discharge proves sinuous nature accelerates with rapid discharge (Fig. 11a). The radius of curvature and channel migration also following the same pattern with river discharge also validates the idea that growing discharge accelerates the erosion rate (Fig. 11b, c). However, channel width becomes narrower in the companioning trend that proves the presence of the depositional process. Mainly, the rapid discharge is only possible in monsoon time. After the peak discharge hustled, the eroding materials are supposed to deposit and increase the amount of sediment flux (Fig. 11d).

\subsubsection{Change in channel migration with discharge}

In this area, channel migration generally occurs through both erosional and accretion processes. The most significant movement observed in 1999-2000 decade, and the amount was $56 \mathrm{~m} \mathrm{y}^{-1}$, whereas, in the present time, migration of channel is too small ( $37 \mathrm{~m} \mathrm{y}^{-1}$ till 2018). It proves due to flooding, the accretion pattern highly increased and originates as a lateral migration process (Fig. 12). 

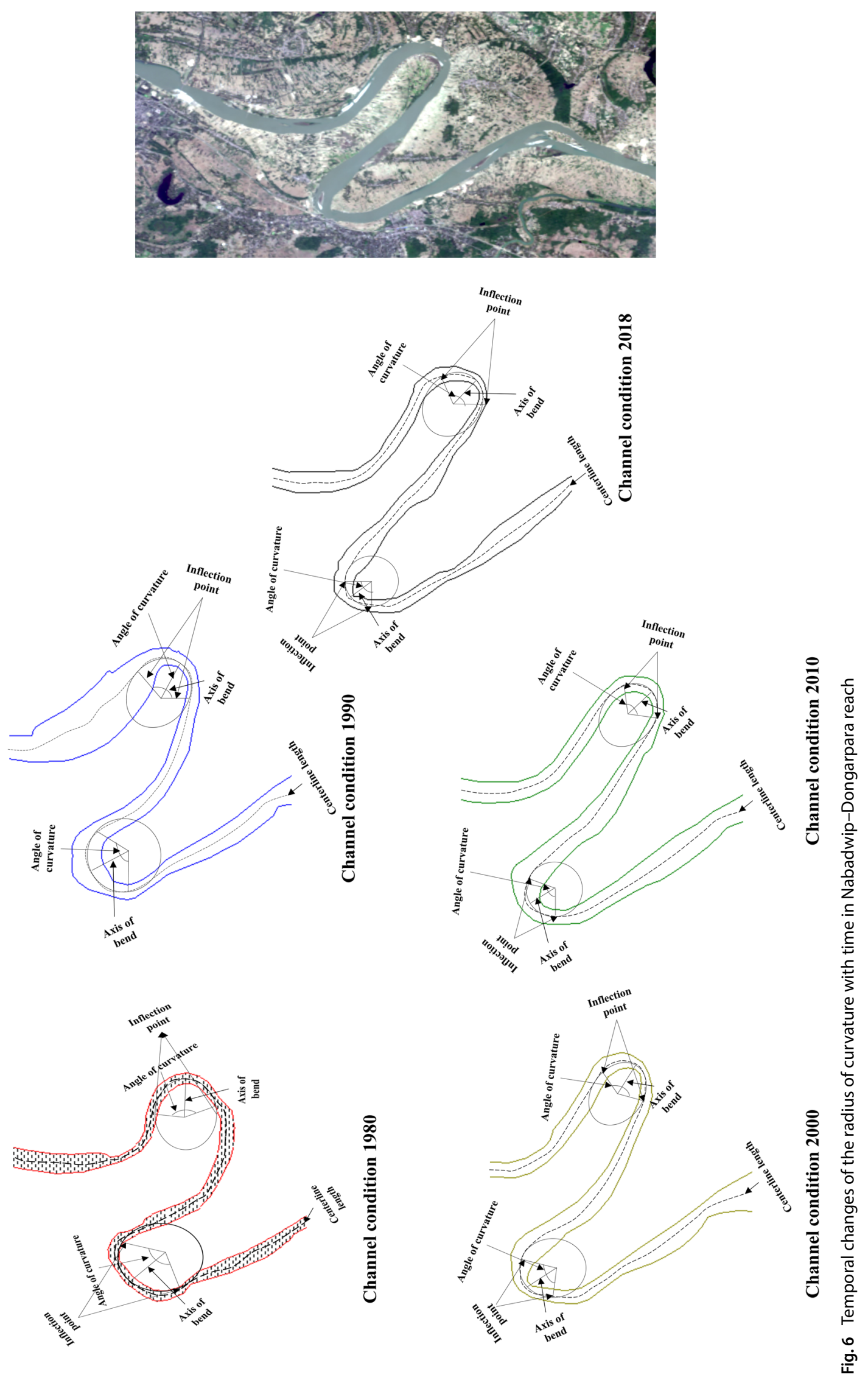
Fig. 7 Trend of the radius of curvature with time

Fig. 8 Trend of BTI with time
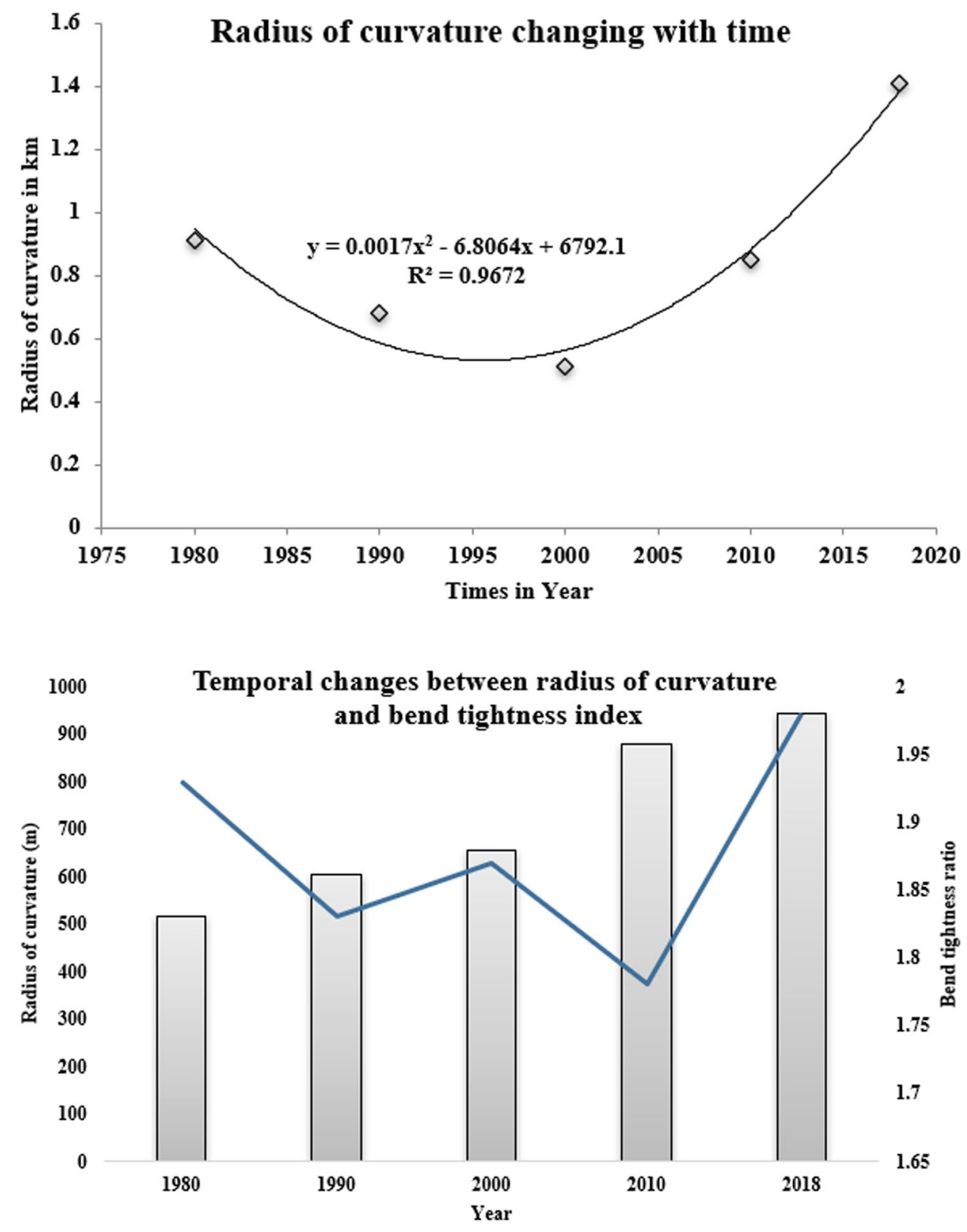

Times in Year

Lateral migration is the central theme of movement in the study area. It effects on riverside banks as erosion and depositional criteria. Logarithmic trend analysis is used here, mainly to show the skewness response to substantial value and to merge the value with percentage change. Multiple regression analysis shows that increasing lateral migration helps increase channel width by time (Fig. 13a). The mean annual discharge and migration plot shows that a high discharge amount relates to the upper movement of the channel through time (Fig. 13b). The meandering river's channel planform shows the highest correlation of migration rate with channel width ratio (Fig. 13c).

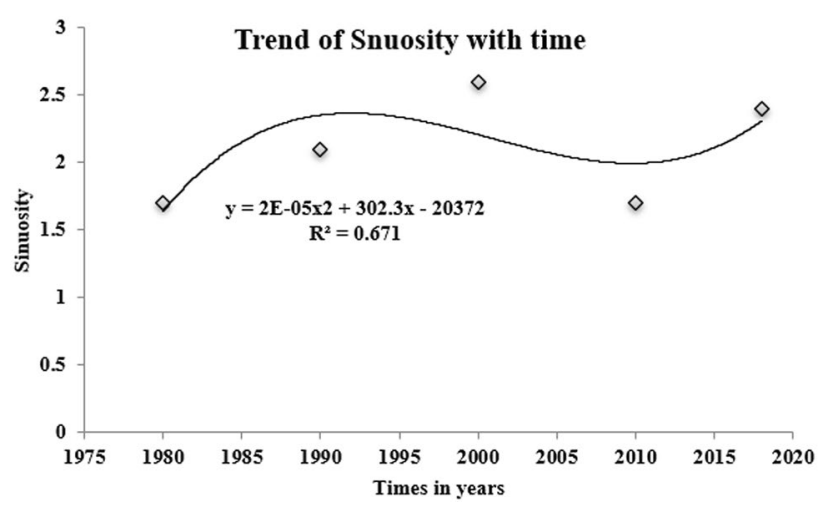

Fig. 9 Changing nature of sinuosity with time 


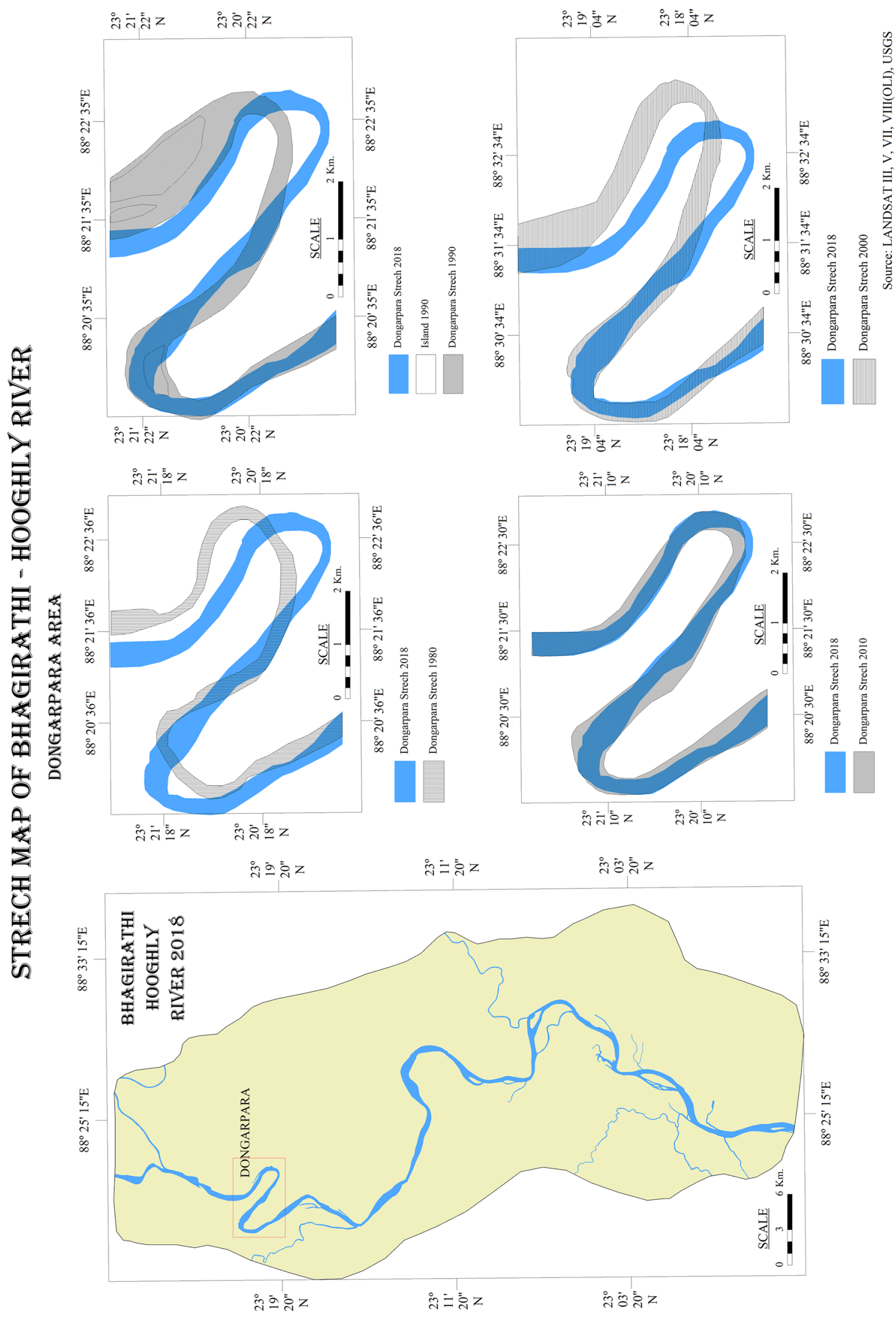

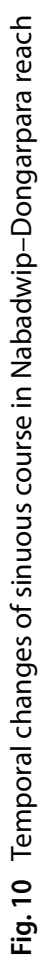



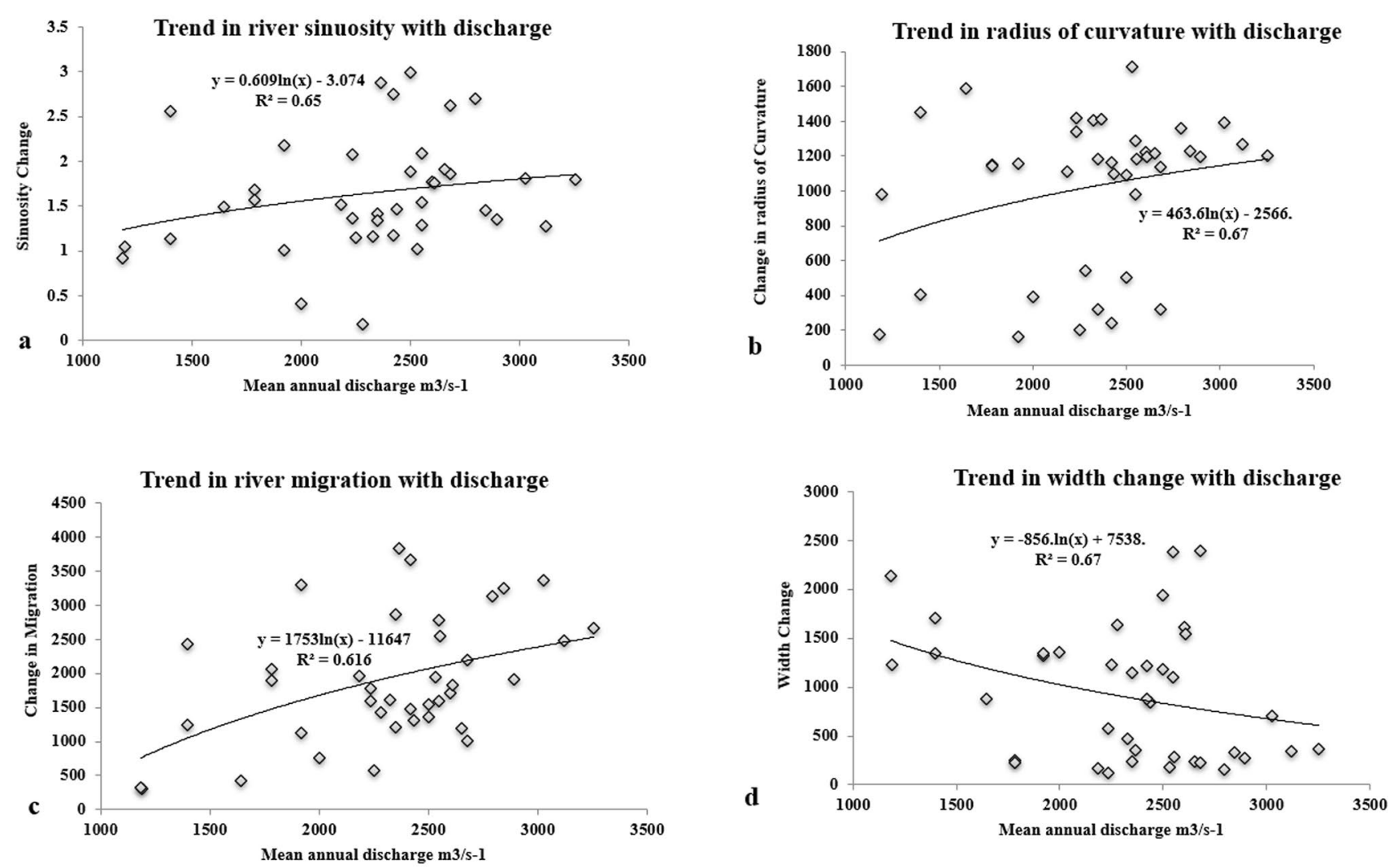

Fig. 11 a Temporal changes in sinuosity by discharge, $\mathbf{b}$ RC by discharge, $\mathbf{c}$ channel migration by discharge, $\mathbf{d}$ channel width by discharge

\section{Decadal shifting of migrated area}

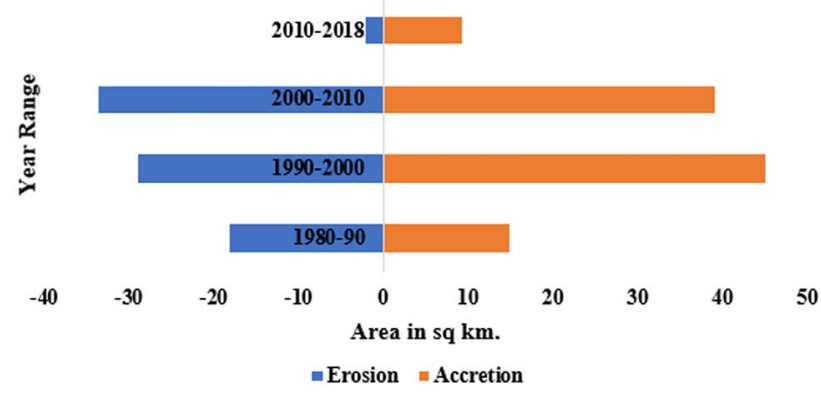

Fig. 12 Decadal shifting of migrated area through erosion and accretion

\subsection{Meandering model by MC approach}

When an actual meander has been formed and developed beautifully in amplitude, bend, the radius of curvature section, and in many cases, it has the status to create a sine-generated curve. However, since the meander's structure is natural and dependent on bank material and soil character, it is impossible to create a real sine-generated curve in nature. With the help of the MC approach, the practical formation of channel curvature and the nature of shifting is graphically discussed in this section. Among the sub-section area, the effects of meandering are most evident in the Nabadwip-Dongapara portion (Fig. 14). This figure shows that the past left bank of $1980\left(t^{*}\right)$ changes with time in the present time $2018\left(\mathrm{t}^{*}+\mathrm{dt}^{*}\right)$, and the same situation occurs in the case of the right bank to $1980\left(t^{*}\right)$ to present position on $2018\left(t^{*}+\mathrm{dt}^{*}\right)$. There are many differences in the position of Nabadwip-Dongapara portion between 1980 and 2018. The meandering part of the river has been moving southwest and northeast section since the 1980s. Changes in river velocity, land use along the river, and persistent bank erosion have exacerbated the situation.

The constant change in velocity and erosion power accelerates the shifting position of the river since the 1980 s. Figure 14 shows the stream coordinate $\left(s^{*}\right)$ varies with the transverse coordinate $\left(n^{*}\right)$ along the sinuous Nabadwip-Dongapara stretch of Bhagirathi-Hooghly river (Eq. 5). The river's main shifting area is located in the northeast portion of the valley centerline. Presumably, the soil character and river banks in this region are conducive to river shifting and erosion. Also, this shifting nature of the river increases the tendency of bank erosion. In this case, as the river's right bank raises the amount of erosion, the left bank also makes a certificate deposit as a result of lowering velocity. With the help of some cross-sections, 

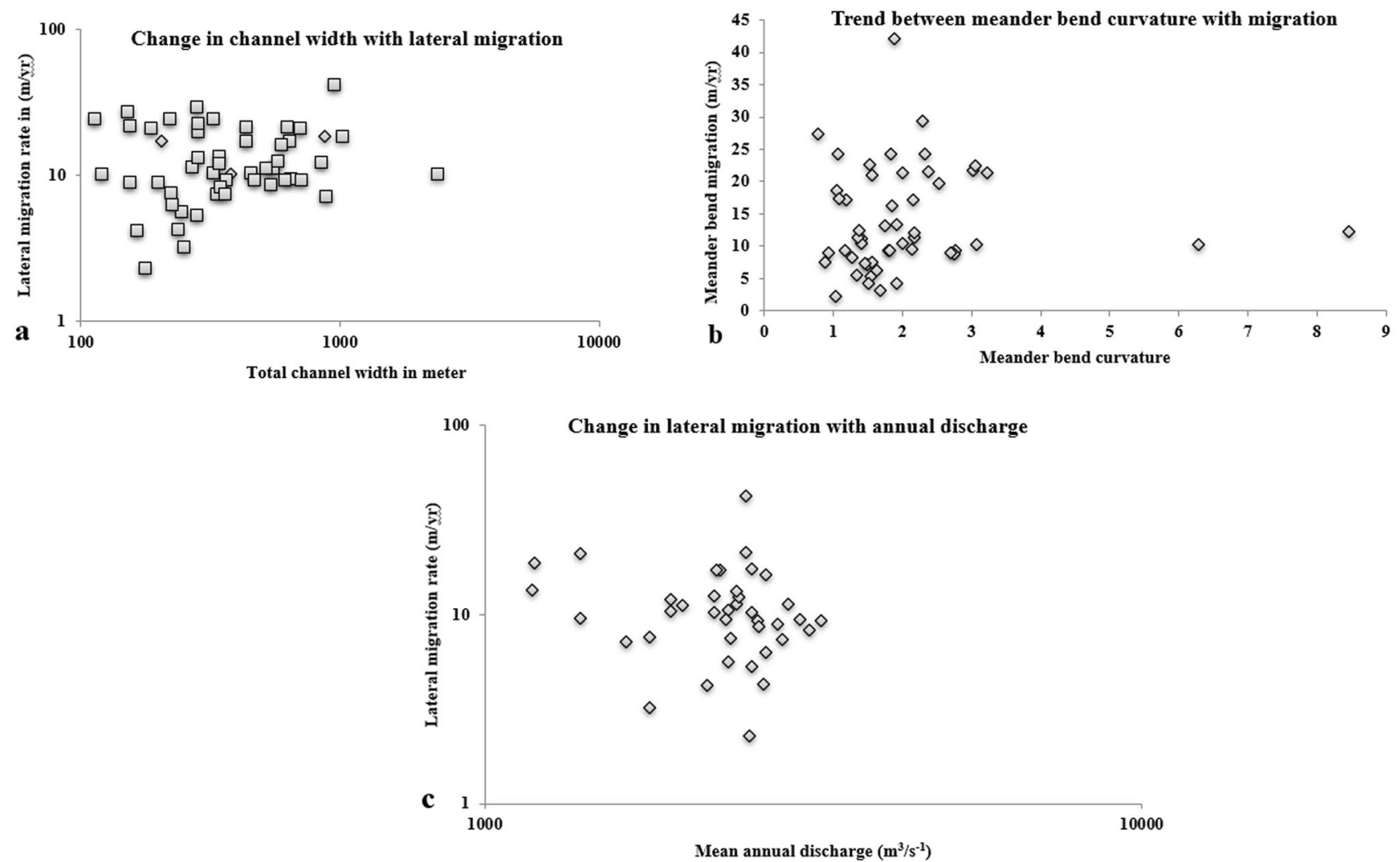

Fig. 13 Temporal changes in a bend curvature with channel migration, $\mathbf{b}$ channel width with lateral migration, $\mathbf{c}$ annual discharge with channel migration

it can be seen that the average velocity along the centerline is much higher. Although the amount of velocity is much higher at river bend, according to the natural law, on the other hand, there is a presence of depositional work. It puts pressure on the outer bank in the transverse coordinates, which gives rise to the meandering process (Eqs. 6, 7). If a point can imagine along the middle of the river, then shifting can be seen along the streamline and transverse coordinates from the centerline of that point. From the discussion on this subject, it is clear that erosion has inextricably been linked with river shifting (Eq. 8). According to the $M C$ approach, the migration of a river depends on certain erosion factors, the nature of the riparian soil, and the river's hydrodynamic conditions (Eq. 9). The region with the most meandering impact in the current study area has met all the criteria of migration by this approach. Although the present discussion has not judged the nature of the soil, judging by the river's discharge and hydrodynamic conditions, the amount of shifting here has been steadily increasing. In the future, the region may isolate from the mainstream, and its most significant impact will occur on the railway line to the west of the area.

\subsection{Temporal change in meandering geometry by time}

Various natural and artificial forces change the course of the river at a different time. In the present study, this situation also prevails from the past. During 38 years of the study period, an enormous amount of changes found in $161 \mathrm{~km}$ reaches. The active channel width also reduced, and the reduction not correlated with peak annual discharge events. This type of yearly discharge peak mainly happens in monsoon time. In pre- or post-monsoon time, the flow amount has reduced, and the high amount of siltation found in the river bed-the river's migration is highly associated with accretion rather erosion. The sinuosity index and radius of curvature also increase in the present time. It indicates the channel change by the accretion process. However, the direction of these changes is not evident in this phase. In the study period, years like 1985, 1991, 1997, 2000, 2005, 2009, 2014 are the primary flood year, and they are repeatedly responsible for channel migration. The most considerable radius curvature value in the study period indicates meander bend curvature 




Fig. 14 Planform configuration and meandering model with time in Nabadwip-Dongarpara stretch [28]

development. After the flood incident in the year 2000, the channel migration rate accelerated rapidly. The channel migration process is higher in the present time, and the number of cut-offs, new channels, and meandering loops also increases.

Figure 15 shows morphological evolution through the changing nature of meander bend change during the study period. The image also indicates their oscillation nature through time. By comparing their migration nature from 1980 to 2018, it proves that gradual migratory behaviour prevails through the region. Nabadwip-Dongarpara portion shows the gradual westward shifting with developing cut-off in the future following by Santipur and Guptipara. However, the later reaches are less affected by the oscillation character of the river. Balagarh is the portion with enormous sediment deposition and char formation. The decreasing nature of flow velocity affected the region also with the unscientific nature of sand mining, which accelerates the process rapidly.

\subsection{Application of MC approach in centerline shifting}

Earlier, the migration of the river and the riverbed location from 1980 to 2018 have been discussed. The best way to understand the river's future position is to examine its centerline and its shifting area. The thalweg line of the river acts as the river centerline in the floodplain area. Although the river's centerline can be traced from 1980 to 2018, various statistical models have been used in previous discussions for future centerlines. The position of the future centerline is determined by discussing the physical and hydrodynamic properties of the MC approach (Eqs. 8, 9).

In the present study area, the spatio-temporal lateral shifting of the centerline is shown by dividing 30 crosssections (Fig. 16). Basically, from a general point of view, these cross-sections have been assigned to places where more shifting is seen or will expect to occur in the future. The MC approach will simulate future centerline based on 

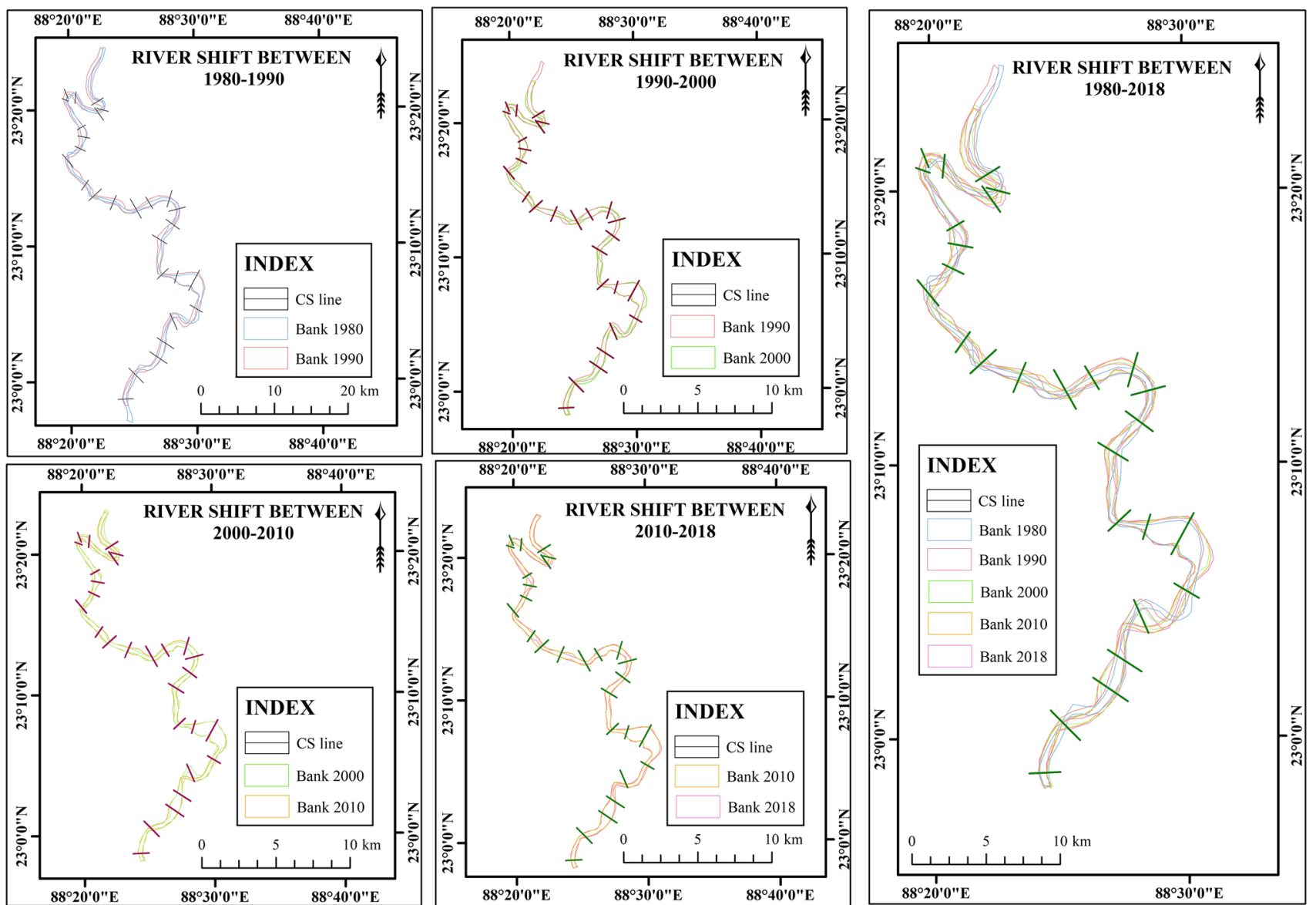

Fig. 15 Spatio-temporal changes of the meandering channel in the sub-catchment basin with cross-sections

cross-sections. One thing to keep in mind is that most of the lateral shifting has occurred eastward than westward portion. In the west portion, near the Kalingar railway station, may consider as the possibility of a significant collapse of the riverbank in the future. The centerline and its future changes based on the left side and right side (negative and positive value) shifting according to each cross-section shown in Table 2. The shifting of mid-channel centerline has been measured for two successive years with a decade breaks of 10 years. The main reason behind this type of centerline may lead due to natural cause or due to loss of the bank's material, excessive flooding, and unscientific use of riparian land. The simulation and prediction centerline will be developed based on accelerating bank failure problems in future.

The observed lateral shift of centerline from 1980 to 2018 shows the maximum right and leftward shifting of $1002.4 \mathrm{~m}(2000-10)$ and $-903.24 \mathrm{~m}(1990-2000)$ in CS 25 , prove maximizing channel width and sedimentation in this particular cross line with the variation in thalweg line in the river bed. The minimum right and leftward shifting of $4.52 \mathrm{~m}$ and $-3.11 \mathrm{~m}$ observes in CS 15 and CS 18
(2000-2010), proves the strength of physical properties in riverbank beside this area. In the crescent of the meandering portion in CS 3 and CS 5 observing to put pressure on the subsequent river bank with increasing flow depth and reach average velocity. As a result, the meandering process enhances to sharpen the amplitude of meander, and a sine-generated curve may prevail in the coming future. Almost all the predicted values by the MC approach shows the rightward movement throughout the sub-section valley. The highest right and a leftward shift of $453.21 \mathrm{~m}$ and - $265.74 \mathrm{~m}$ may avail in CS 23 (2040) and CS 22 (2030) with accelerating width change in the river bed. The lowest right and a leftward shift of $6.62 \mathrm{~m}$ and $-8.24 \mathrm{~m}$ may occur in CS 24 (2030) and CS 28 (2040) with diminishing width change and urban land use. The observed and predicted centerline value through the $M C$ approach evaluated through the coefficient of determination $\left(R^{2}\right)$ and RMSE (root mean square error). The $R^{2}$ value depicts a good linear relationship between observed and predicted value $\left(R^{2}=0.80\right.$ to 0.88 ) in CS 10,11, 14-22 and 30. The lowest RMSE value indicates the minimum error with confirming validation in predicted results. The lowest and highest RMSE observes in 
Fig. 16 Spatio-temporal channel centerline shifting and prediction by MC approach with 30 cross-sections

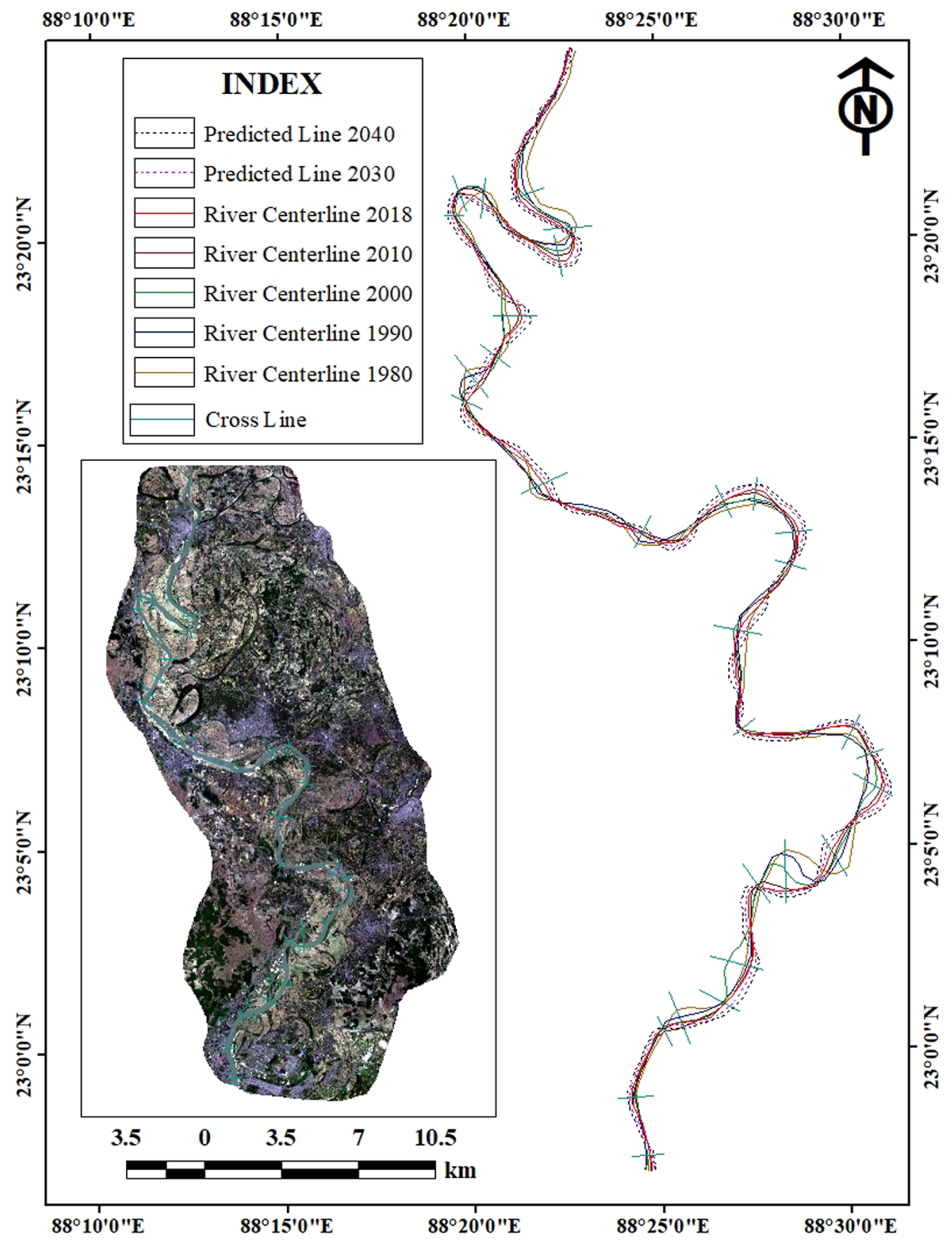

CS 7 and CS 27, respectively. It is hoped that the predicted values would come true in the future, and the state government will adopt an action plan based on them.

\subsection{Effect of centerline shifting on velocity}

According to the MC approach, velocity and discharge of meandering rivers are very important for river migration. From the period of 1980 to 2018 , it proved that the amount and velocity of discharge have decreased with time. In some cases, channel width has become an essential factor (Eqs. 8, 9). The velocity has increased due to lower channel width proportionately at the starting point of the sub-section of the river at Nabadwip. If we go from the beginning to the end (Kalyani) of the sub-section, we can see that the velocity and discharge decrease with increasing distance (Fig. 14). As a result, sedimentation has been observed in some parts of the river bed with sand bar formation. The channel width increases with the sand bar, and this growth rate remains unchanged in the future. Being a monsoon dominated sub-section, the river itself clears the bar formation from his bed in the time of the flood-the rate of sand bar formation changes with centerline formation of the river, decade wise. The nature of velocity change by distance and width depicts in the figure below (Fig. 17a, distance from the source point of this sub-section area b). The velocity and discharge decrease with increasing 
Table 2 Channel centerline shifting and prediction with validation

\begin{tabular}{|c|c|c|c|c|c|c|c|c|c|}
\hline $\begin{array}{l}\text { Cross- } \\
\text { section } \\
\text { number }\end{array}$ & Stretches & $1980-1990$ & $1990-2000$ & $2000-2010$ & $2010-2018$ & $2018-2030$ & $2030-2040$ & RMSE & $\mathrm{R}^{2}$ \\
\hline CS 1 & Nabadwip-Dongarpara & -292.36 & -153.25 & -114.52 & -87.53 & -176.28 & -165.25 & 1.62 & 0.71 \\
\hline $\mathrm{CS} 2$ & & 238.53 & 26.87 & 224.25 & 131.94 & 110.17 & 159.71 & 3.79 & 0.69 \\
\hline CS 3 & & 88.77 & 231.81 & 250.43 & 256.92 & 214.94 & 212.45 & 1.27 & 0.68 \\
\hline CS 4 & & 67.11 & -76.15 & -26.11 & -377.91 & -138.09 & 132.64 & 19.34 & 0.66 \\
\hline CS 5 & & -688.11 & 44.25 & -55.36 & 107.36 & -144.26 & -138.44 & 1.29 & 0.67 \\
\hline CS 6 & & 171.58 & 32.56 & 89.33 & 12.31 & 56.12 & 61.32 & 3.51 & 0.65 \\
\hline CS 7 & Samudragarh-Dhatrigram & -219.79 & -10.71 & 746.52 & 149.23 & 165.33 & 167.72 & 0.043 & 0.65 \\
\hline CS 8 & & 185.03 & -156.22 & 145.70 & 40.43 & 68.14 & 71.63 & 3.36 & 0.64 \\
\hline CS 9 & & 303.13 & 461.15 & 157.18 & -99.15 & -214.13 & -209.63 & 89 & 0.64 \\
\hline CS 10 & & 218.71 & -22.63 & -137.12 & -17.12 & -12.33 & -21.31 & 5.95 & 0.81 \\
\hline CS 11 & Kalna-Balagarh & 219.31 & 125.07 & -9.31 & 286.71 & 182.22 & 152.76 & 2.61 & 0.80 \\
\hline CS 12 & & 146.86 & -374.71 & -97.31 & 144.31 & 52.36 & -17.18 & 14.37 & 0.79 \\
\hline CS 13 & & 235.51 & 91.23 & 105.08 & -3.21 & -107.34 & -93.74 & 48.95 & 0.79 \\
\hline CS 14 & & 158.87 & 113.30 & 266.17 & 147.75 & 164.52 & 180.76 & 0.271 & 0.80 \\
\hline CS 15 & & -108.32 & 82.78 & 4.52 & 160.91 & 39.96 & 33.91 & 0.57 & 0.84 \\
\hline CS 16 & & 145 & 95 & 11.13 & -21.97 & -50.76 & -63.37 & 29.53 & 0.83 \\
\hline CS 17 & Balagarh-Jirat & -442.31 & 160.93 & 252.36 & -21.74 & -98.86 & -111.62 & 24.74 & 0.83 \\
\hline CS 18 & & 8.17 & 80.83 & -3.11 & -18.85 & -11.36 & 12.37 & 4.51 & 0.84 \\
\hline CS 19 & & -160.41 & 495.63 & 38.91 & 32.28 & 103.39 & 110.76 & 1.57 & 0.85 \\
\hline CS 20 & & 6.31 & 190.54 & 57.69 & -11.36 & 61.37 & 61.91 & 0.255 & 0.85 \\
\hline CS 21 & & 72.61 & 417.55 & 253.02 & 185.49 & 233.52 & 234.51 & 0.584 & 0.86 \\
\hline CS 22 & Jirat-Magra-Kuntighat-Tribeni & -482.51 & -240.21 & -65.66 & -274.14 & -265.74 & -112.4 & 25.52 & 0.85 \\
\hline CS 23 & & 162.08 & 661.79 & 863.39 & 76.32 & 448.74 & 453.21 & 3.56 & 0.79 \\
\hline CS 24 & & -140.21 & 43.11 & -155.26 & 201.36 & 6.62 & 18.52 & 9.57 & 0.74 \\
\hline CS 25 & & 116.37 & -903.24 & 1002.4 & 12.14 & 63.71 & 59.62 & 1.94 & 0.79 \\
\hline CS 26 & & -68.11 & 53.63 & 72.91 & 21.31 & 11.71 & 8.91 & 4.30 & 0.51 \\
\hline CS 27 & & 300.08 & 243.13 & 214.34 & -181.98 & -149.23 & -159.62 & 149.16 & 0.58 \\
\hline CS 28 & & -147.25 & 13.14 & 222.13 & -140.23 & -14.74 & -8.24 & 0.92 & 0.62 \\
\hline CS 29 & & -100.85 & 115.52 & -73.14 & -109.25 & -43.15 & -40.36 & 0.147 & 0.57 \\
\hline CS 30 & & -159.17 & 85.39 & 98.34 & 29.35 & 17.42 & 36.97 & 13.72 & 0.87 \\
\hline
\end{tabular}

Positive value indicates the shifting in the right side and negative value indicates the shifting in the left side-all the shifting values in meter (m)

(Nabadwip-Kalyani stretch), which may increase the amount of riverbank erosion and river migration in the future (Fig. 17d, e).

\subsection{Validation of centerline shifting through cross-profile:}

Several cross profiles are shown based on the observed and simulated centerline to quantify the MC approach model performance. Here are four cross-profile points in moving forward with spatio-temporal lateral shifting. Since there are many cross-sections, it is impossible to show the profiles of all of them. So, these four crosssections were chosen. The effect of meandering on them appears to increase the depth and velocity in CS
3,5 , and 15 . The amount of sedimentation also seems to increase by decreasing the velocity in CS 20. After the calibration of profiles, it has been observed that the shifting of the centerline would continue in the future while maintaining the current trend (Fig. 18). Observations and simulated centerlines have been predicted at intervals of 20 years. There is a westward trend of temporal, lateral shifting of the centerline in all the cross profile except the CS 5. In CS 3, the direction shows the centerline's present position near the left portion of the bank, but it may become more profound in 2040. The eastward lateral shifting may prevail in CS 5, and it will become destructive for the eastern railway line shortly (Fig. 17c). Not only the erosion, CS 15 and CS 20 may exhibit depositional behaviour in future. Since the 

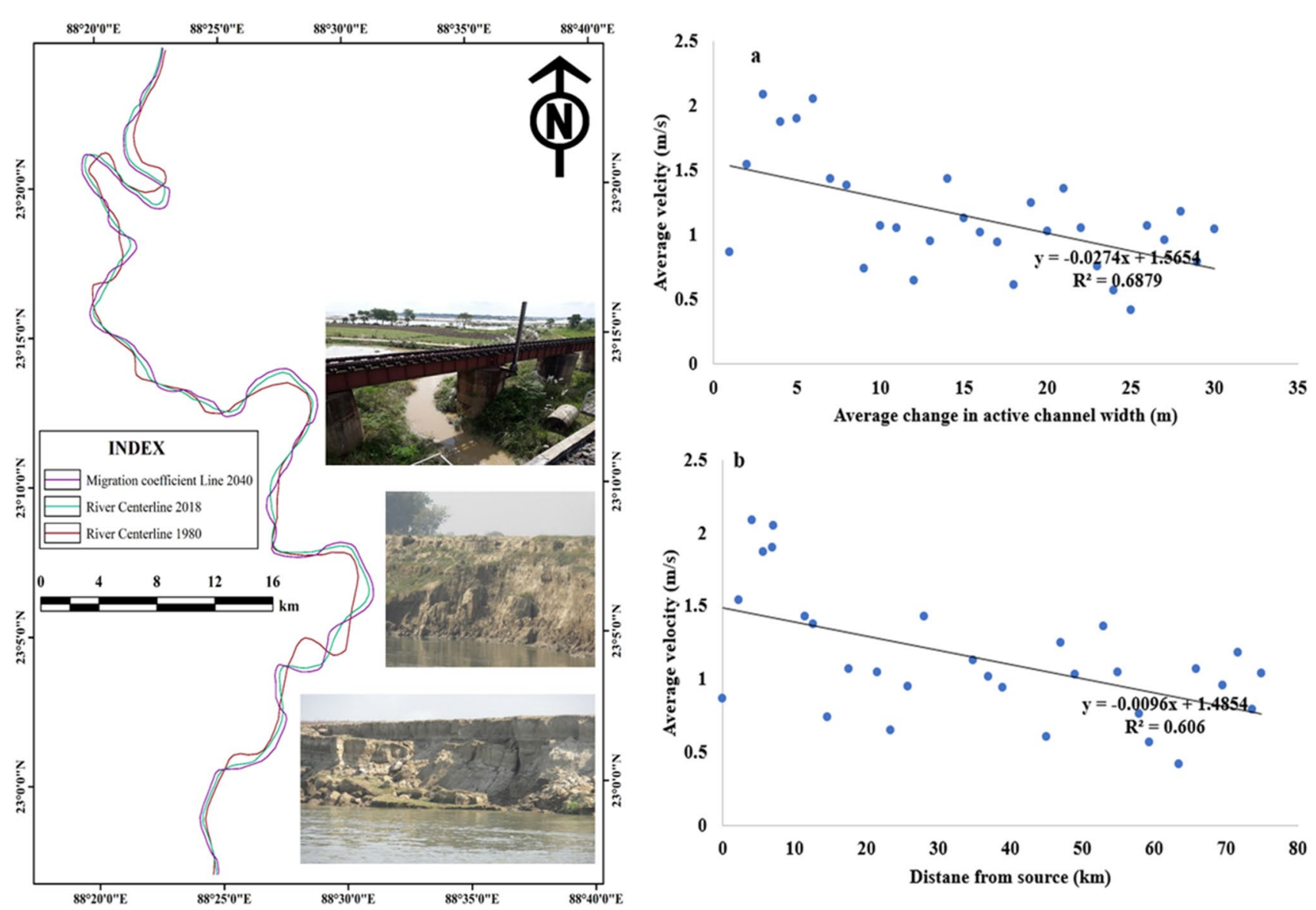

Fig. 17 Comparison between historic (1980), Observed (2018) and simulated (2040) channel centerline by MC approach a velocity change with channel width, $\mathbf{b}$ velocity change with distance, $\mathbf{c}$ affected railway bridge near Kalinagar station, $\mathbf{d}$, e effect of velocity increase

trend of the river shows the diminishing rate with active channel width in the present, and it will also prevail in the future. As the channel becomes flatter in the lower portion of the sub-section valley, the river's velocity and carrying capacity will decrease with width. If the same trend prevails in future, the reach average velocity, erosion power, and flow depth may decline in 2040 . So, the channel centerline may shift, but the intensity will fall from the present situation.

Judging by the above cross-section, it has been seen that there is a proportional relation of velocity with the depth of the centerline (Fig. 19). Observable years show that velocity increases with increasing depth at CS 3, 5, and 15. In other words, velocity has increased in centerline depth (thalweg depth) of this region (Fig. 14). These three cross-sections show a strong linear relationship between depth and velocity, which will continue until 2040. However, according to CS 20, centerline depth decreases with the velocity. On the other hand, the depositional process accelerates with a diminishing rate of velocity as well as erosion. The channel width has increased due to sedimentation, giving birth to the sand bar formation in its terrain. The progress of the sedimentation trend may increase in the future until 2040.

\section{Conclusion and recommendations}

From the above discussion, the future position of meandering along a specific sub-section basin of BhagirathiHooghly river (Navadwip-Kalyani stretch) from 1980 to 2018 analysed through meandering geometry and its nature and the migration coefficient (MC) approach. Satellite imagery reveals past and present river channels, their location, and their changes over the decades. In this sub-section basin, the nature of Bhagirathi-Hooghly distributary is so vigorous that it has caused severe bank erosion throughout the channel. Several prior studies show the flowing index on account of the structure of the Farakka barrage for the fluctuation $[51,53,55,57$, 58]. The water dispute treaty with Bangladesh and the diminishing discharge amount caused the higher sedimentation and narrowing of the valley, which caused 
Fig. 18 Observed and simulated cross-profile changes with centerline by MC approach

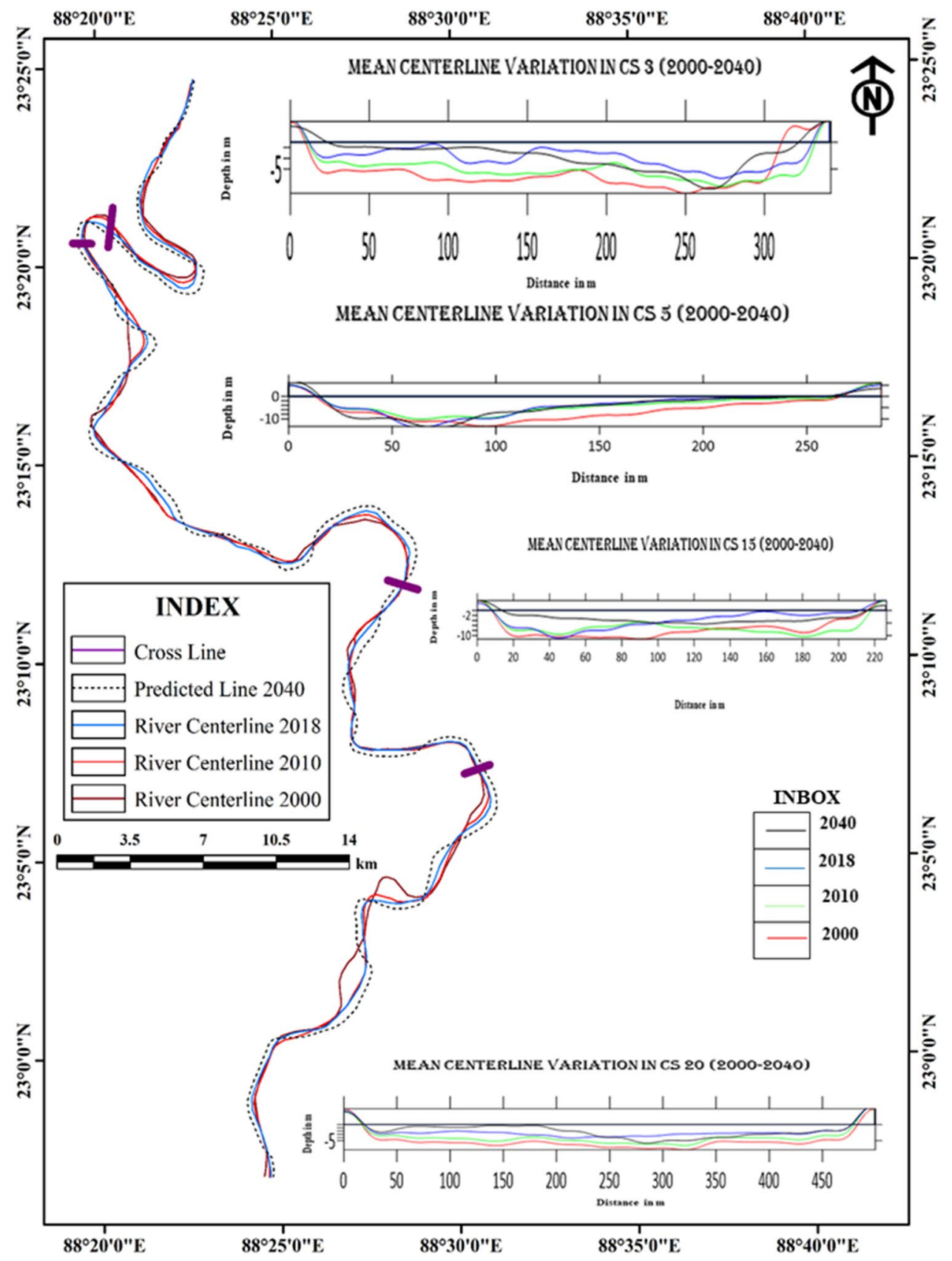

the flood in monsoon and post-monsoon season. This region's bank material is shaped with non-cohesive sand in the lower part through the cohesive clayey substance with upper coating. After the flood cycle in the monsoon period, the bank material can be cracked by frequent moist and dry cycle in the post and pre-monsoon time by decreasing their shear stress condition. The erosional potential of the river has been reduced, and the river turned into a flood-prone zone. The quantity of land loss is mainly caused due to unscientific construction and intervention.
The whole discussion has been divided into two parts. The characteristics of meandering are discussed geometrically after knowing the position of the bend from the satellite image. From this discussion, it is understood that while the amount of active channel width and river discharge decreases over time, the radius of curvature, sinuosity index, and channel migration is increasing. As a result, the meandering process with the amount of migration is growing continuously. The meandering geometry and sinuous pattern of Nabadwip-Dongarpara portion show a south-eastward movement in the eastern part and 


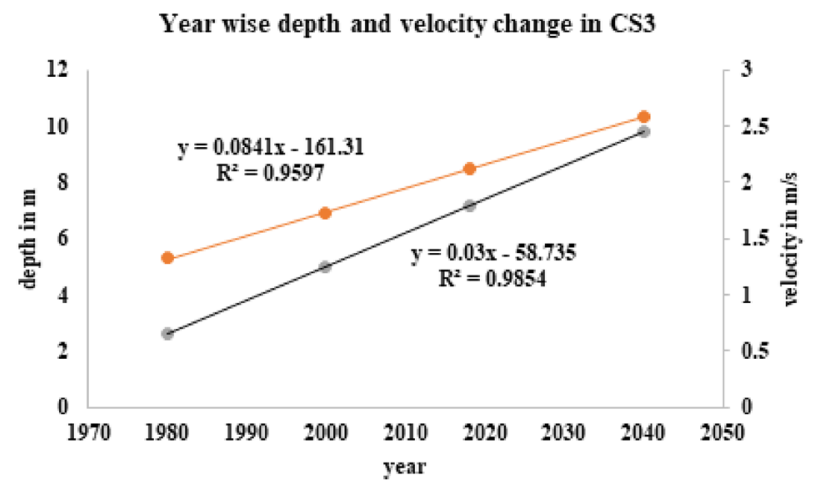

Year wise depth and velocity change in CS15

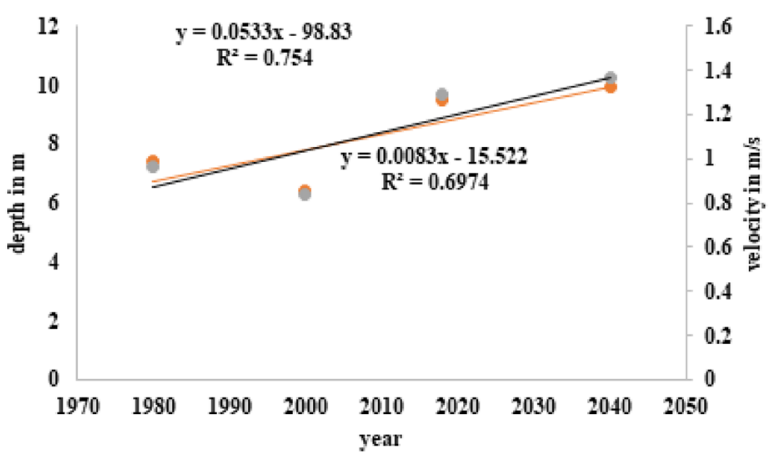

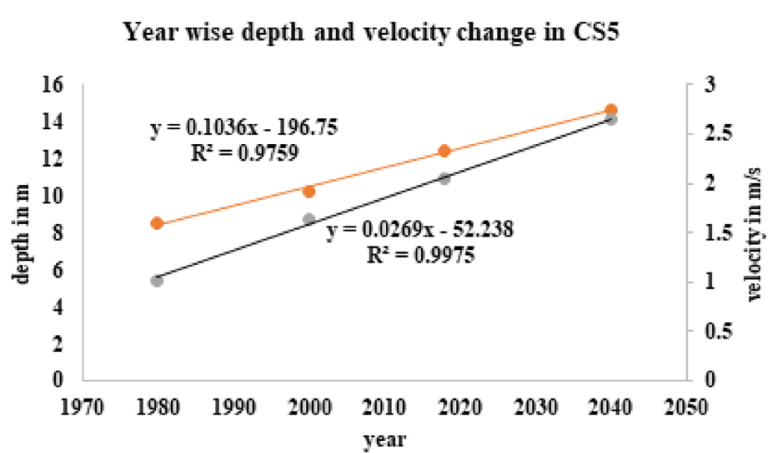

Year wise depth and velocity change in CS20

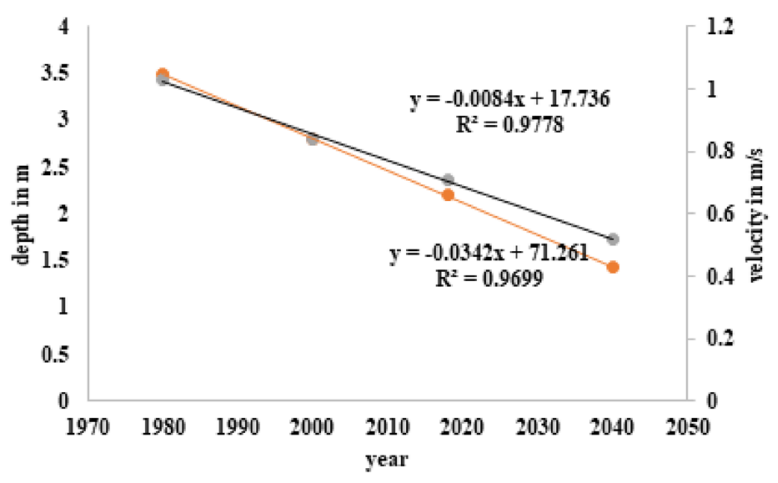

Depth variation

Velocity variation

Fig. 19 Observed and simulated depth-wise velocity changes in centerline by MC approach

north-west movement on the western side. It will predict that there will be a neck cut-off in future, which affects the local populace by accelerating the process of riverbank erosion. So, the empirical formula called the MC Approach has been used to find out the exact cause and nature of the migration in the meandering river. The emphasis has been put on near-bank velocity and migration coefficients through the MC approach.

The migration coefficient calibrates the river's centerline from 1980 to 2018 and predicts the future centerline's location. Although the river's future condition simulates by the position of centerline, this approach does not highlight the continuous erosion and erosion procedures of the river, the hydrodynamic and morphodynamical character of the river. All centerline locations have been grouped into 30 cross-sections. Most of the 2030s and 2040s prediction have seen the right word movement from the previous centerline. However, CS 3-6 (Navadwip-Samudragarh stretch) is a bit of a sine-generated mending curve, so the river's leftward diversion is evident here. It is assumed that this leftward movement would cause severe damage to the Eastern Railway line near Kalingar station in the future. Discussions on near bank velocity show that velocity has a disproportionate relationship with active channel width. Though the velocity in river bends has increased in the CS 3-6 (Nabadwip-Samudragarh stretch) area, the CS 19-25 region's velocity is comparatively much lower than the beginning portion of the study area. As a result, the sand bar formation trend is seen along the river bed at the bottom of the sub-section. The rate of bank erosion is expected to increase in future (2040) with the changing nature of the centerline position of the river.

CS 25 is the most viable cross-section, as it has the highest shifting trend, both right and leftward, which will continue in the future. RMSE and $R^{2}$ calculations validate the entire MC approach. After discussing all the observing and predicting data, most of the CS indicates a positive linear relationship with $R^{2}$ value, and the lowest RMSE value has seen along several cross-sections. As the RMSE value of CS 14, 15, 20 and 21 are small, and the $R^{2}$ value indicates 
a strong positive direction, these CS's have the best position in terms of observation and prediction in the river migration trend.

From this discussion, with the help of migration coefficient (MC) approach, the future condition of river centerline has been predicted. In future, if the possibility of collecting bank material, soil properties and bank character can be achieved, then further prediction of future shifting with resultant bank erosion can be simulated and predicted in the study area. A governmental action plan should be essential here to eradicate the future river bank erosion problem. The local riverside stakeholder is mainly affected due to the erosion. The prediction of the centerline shifting provides us with valuable information about the inundation of riverside land loss and resultant neo-refugee problems among the inundated stakeholder. Long term prediction with local station survey is significant to protect riverside property. So, the government should collect data and make a particular policy based on the pattern of this centerline shifting.

Acknowledgements The authors are showing sincere gratitude to Kolkata port trust (hydrography section) for providing the hydro dynamic, past bathymetric and discharge data of the sub-catchment section (Nabadwip-Kalyani stretch) of Bhagirathi-Hooghly river. The authors are also acknowledging gratitude to the Digital Library of School of Water Resources Engineering, Jadavpur University, for allowing to access all the GIS and statistical software. The authors are grateful to the anonymous reviewers for their comments for the rectification of the article.

\section{Compliance with ethical standards}

Conflict of interest There is no conflict of interest among the authors.

\section{References}

1. Surian N, Rinaldi M (2003) Morphological response to river engineering and management in alluvial channels in Italy. Geomorphology 50:307-326. https://doi.org/10.1016/S0169 $-555 \times(02) 00219-2$

2. Luppi L, Rinaldi M, Teruggi LB, Darby SE, Nardi L (2009) Monitoring and numerical modelling of riverbank erosion processes: a case study along the Cecina River (Central Italy). Earth Surf Proc Land 2148:2133-2148. https://doi. org/10.1002/esp.1754

3. Hudson PF, Kessel RH (2000) Channel migration and meander bend curvature in the lower Mississippi river prior to major human modification. Geology 28(6):531-534. https://doi. org/10.1130/0091-7613(2000)28<531:CMAMCl>2.0.CO;2

4. Keesstra SD, Van Huisstenden J, Vandenberghe J, Van Dam O, De Gier J, Pleizier ID (2005) Evolution of the morphology of the river Dragonja (SW Slovenia) due to land-use changes. Geomorphology 69:191-207. https://doi.org/10.1016/j.geomo rph.2005.01.004
5. Kuntjoro SI, Harijanto D (2017) Discharge fluctuation effect on meandering river bends evolution. IOP Conf Ser Mater Sci Eng 267:012032. https://doi.org/10.1088/1757-899X/267/1/012032

6. Mirazee S, Yousefi S, Keestra S, Pourghasemi HR, Cerda A, Fuller C (2018) Effects of hydrological events on morphological evolution of a fluvial system. J Hydrol 563:33-42. https://doi. org/10.1016/j.jhydrol.2018.05.065

7. Carlston CW (1965) The relation of free meander geometry to stream discharge and its geomorphic implications. Am J Sci 263:864-885. https://doi.org/10.2475/ajs.263.10.864

8. Ball J (1942) Egypt in the classical geographers. Servery of Egypt, Government Press, Cairo

9. Hillier JK, Bunbury JM, Graham A (2007) Monuments on a migrating Nile. J Archaeol Sci 34(7):1011-1015. https://doi. org/10.1016/j.jas.2006.09.011

10. Jeffreys DG (1985) Survey of Memphis I. Egypt Exploration Society, London

11. Graham A, Bunbury J (2005) The ancient landscapes and waterscapes of Karnak. Egypt Archaeol 27:17-19

12. Leopold LB, Wolman MG (1960) River Meanders. Bull Geol Soc Am 71:769-794

13. Thorne CR, Lewin J (1979) Bank processes, bed material movement and planform development in a meandering river. In: Rhodes DD, Williams GP (eds) Adjustments of the fluvial system. Kendall/Hunt Pub Co, Dubuque, pp 117-137

14. Hickin EJ (1974) The development of meanders in natural river channels. Am J Sci 274:414-442

15. Nanson GC, Young RW (1981) Overbank deposition and floodplain formation on small coastal streams of New South Wales. Zeitschrift für Geomorphologie 25(3):332-347

16. Hickin EJ (1983) River channel changes, retrospect and prospect. In: Collinson JD, Lewin J (eds) Modern and ancient fluvial systems: International Association of Sedimentologists Special Publication, vol 6. Wiley, Hoboken, pp 61-83

17. Hickin EJ, Nanson GC (1975) The character of channel migration on the Beatton River, northeast British Columbia, Canada. Geol Soc Am Bull 86:487-494

18. Edwards BF, Smith DH (2002) River meandering dynamics. Phys Rev E 65:046303. https://doi.org/10.1103/PhysR evE.65.046303

19. Nicoll TJ, Hickin EJ (2010) Planform geometry and Channel migration of confined meandering rivers on the Canadian prairies. Geomorphology 116:37-47. https://doi.org/10.1016/j. geomorph.2009.10.005

20. Chu ZX, Sun XG, Zhai SK, Xu KH (2006) Changing pattern of accretion/erosion of the modern yellow river (Huanghe) subaerial delta, China: based on remote sensing images. Mar Geol 227:13-30. https://doi.org/10.1016/j.margeo.2005.11.013

21. Gregory KJ (2006) The human role in changing river channels. Geomorphology 79:172-191. https://doi.org/10.1016/j.geomo rph.2006.06.017

22. Marston RA, Girel J, Pautou G, Piegay H, Bravard J-P, Arneson $C$ (1995) Channel metamorphosis, floodplain disturbance and vegetation development: Ain River, France. Geomorphology 13:121-131. https://doi.org/10.1016/0169-555X(95)00066-E

23. Richard GA, Julien PY, Baird DC (2005) Statistical analysis of lateral migration of the Rio Grande, New Mexico. Geomorphology 71:139-155. https://doi.org/10.1016/j.geomorph.2004.07.013

24. Camporeale C, Ridolfi L (2010) Interplay among river meandering, discharge stochasticity and riparian vegetation. J Hydrol 382:138-144. https://doi.org/10.1016/j.jhydrol.2009.12.024

25. Fremier AK, Girvetz EH, Greco SE, Larsen EW (2014) Quantifying Process-based mitigation strategies in historical context: separating multiple cumulative effects on river meander migration. PLoS ONE 9(6):1-8. https://doi.org/10.1371/journal.pone.00997 36 
26. Guneralp I, Rhoades BL (2008) Continuous characterization of the planform geometry and curvature of meandering rivers. Geogr Anal 40:1-25. https://doi.org/10.111 1/j.0016-7363.2007.00711.x

27. Thakur PK, Laha C, Aggarwal SP (2012) River bank erosion hazard study of river Ganga, upstream of Farakka Barrage using remote sensing and GIS. Nat Hazards 61:967-987. https://doi. org/10.1007/s11069-011-9944-z

28. Yang C, Cai X, Wang X, Yan R, Zhang T, Zhang Q, Lu X (2015) Remotely sensed trajectory analysis of channel migration in lower Jingjiang reach during the period of 1983-2015. Remote Sens 7:16241-16256. https://doi.org/10.3390/rs71215828

29. Billah MM (2018) Mapping and monitoring erosion-accretion in an alluvial river using satellite imagery-the river bank changes of the Padma River in Bangladesh. Quaest Geogr 37(3):87-95. https://doi.org/10.2478/quageo-2018-0027

30. Suhaimi HM, Jamal MH, Ahmad A (2018) Assessment of river bank erosion at Kilim River, Langkawi using geospatial technique. IOP Conf Ser Earth Environ Sci 169:1-10

31. Peixotoa JM, Nelson BW, Wittmann F (2009) Spatial and temporal dynamics of river channel migration and vegetation in central Amazonian white-water floodplains by remote-sensing techniques. Remote Sens Environ 113:2258-2266. https://doi. org/10.1016/j.rse.2009.06.015

32. Darby SE, Alabyan AM, Van De Wiel MJ (2002) Numerical simulation of bank erosion and channel migration in meandering rivers. Water Resour Res 38(9):1163-1184. https://doi. org/10.1029/2001WR000602

33. Jana S (2019) An automated approach in estimation and prediction of riverbank shifting for flood-prone middle-lower course of the Subarnarekha river, India. Int J River Basin Manag. https ://doi.org/10.1080/15715124.2019.1695259

34. Blondeaux P, Seminara G (1985) A unified bar-bend theory of river meanders. J Fluid Mech 157:449-470. https://doi. org/10.1017/S0022112085002440

35. Sun T, Meaking P, Jossang T, Schwarz K (1996) A simulation model for meandering rivers. Water Resour Res 32(9):29372954. https://doi.org/10.1029/96WR00998

36. Zolezzi G, Seminara G (2001) Downstream and upstream influence in river meandering. Part I. General theory and application to over deepening. J Fluid Mech 438:183-211. https://doi. org/10.1017/S0022112001004281

37. Lancaster ST, Bras RL (2002) A simple model of river meandering and its comparison to natural channels. Hydrol Process 16(1):126. https://doi.org/10.1002/hyp.273

38. Hasegawa K (1977) Computer simulation of the gradual migration of meandering channels. In: Proceedings of the Hokkaido Branch, Japan Society of Civil Engineering, pp 197-202 (in Japanese)

39. Ikeda S, Parker G, Sawai K (1981) Bend theory of river meanders. Part I. Linear development. J Fluid Mech 112:363-377. https:// doi.org/10.1017/S0022112081000451

40. Motta D, Abad JD, Langendoen EJ, Garcia MH (2012) A simplified 2D model for meander migration with physically-based bank evolution. Geomorphology 163-164:10-25. https://doi. org/10.1016/j.geomorph.2011.06.036

41. Abad JD, Garcia MH (2006) RVR Meander: a toolbox for re-meandering of channelized streams. Comput Geosci 32:92-101. https ://doi.org/10.1016/j.cageo.2005.05.006

42. Motta D, Fernández R, Abad JD, Langendoen EJ, Oberg N, Garcia MH (2011) RVR Meander-User's manual. USDA ARS National Sedimentation Lab, pp 1-20

43. Pourbakhshian S, Pouraminian M (2015) Stochastic modelling to prediction of river morphological changes. Indian J Sci Technol 36:289-297. https://doi.org/10.17485/ijst/2015/v8i11/71772
44. Deb M, Ferreira C (2015) Planform channel dynamics and bank migration hazard assessment of a highly sinuous river in the north-eastern zone of Bangladesh. Environ Earth Sci 73:66136623. https://doi.org/10.1007/s12665-014-3884-3

45. Akhter S, Eibek KU, Islam S, Md RA, Islam T, Chu R, Shuanghe S (2019) Predicting spatiotemporal changes of channel morphology in the reach of Teesta river, Bangladesh using GIS and ARIMA modelling. Quatern Int 513:80-94. https://doi.org/10.1016/j. quaint.2019.01.022

46. Bag R, Mondal I, Bandyopadhyay J (2019) Assessing the oscillation of channel geometry and meander migration cardinality of Bhagirathi River, West Bengal, India. J Geogr Sci 29(4):613-634. https://doi.org/10.1007/s11442-019-1618-z

47. Bagchi K (1944) The Ganges delta. University of Calcutta, Calcutta

48. Bandyopadhyay S (1996) Location of the Adi Ganga palaeo channel, South 24 Parganas, West Bengal: a review. Geogr Rev India 58:93-109

49. Bandyopadhyay S, Das S, Kar NS (2015) Discussion: "Changing river courses in the western part of the Ganga-Brahmaputra delta" by K. Rudra (2014), Geomorphology 227: 87-100. Geomorphology 250:442-453. https://doi.org/10.1016/j.geomo rph.2015.02.037

50. Bandyopadhyay S, Kar NS, Das S, Sen J (2014) River systems and water resources of West Bengal: a review. Spec Publ Geol Soc India 3:63-84

51. Basu SR (2005) Recent findings on the river dynamics of Bengal: Post-Farakka condition of the off-take and bank erosion of the River Bhagirathi-Hugli. Geogr Rev India 67:315-346

52. Majumder SC (1942) Rivers of the Bengal delta. University of Calcutta, Calcutta

53. Rudra K (1981) Identification of the ancient mouths of the Ganga as described by Ptolemy. Geogr Rev India 43:97-104

54. Rudra K (2008) Banglar Nadikatha. Sahitya Samsad, Kolkata

55. Rudra K (2010) Dynamics of the Ganga in West Bengal, India (1764-2007)-implications for science-policy interaction. Quatern Int 227:161-169. https://doi.org/10.1016/j.quain t.2009.10.043

56. Mukherjee R (2009) The changing face of Bengal. University of Calcutta, Kolkata

57. Rudra K (1987) Quaternary history of the lower Ganga distributaries. Geogr Rev India 49:38-48

58. Rudra K (2014) Changing river courses in the western part of the Ganga-Brahmaputra delta. Geomorphology 227:87-100. https ://doi.org/10.1016/j.geomorph.2015.04.031

59. Laha C (2015) Oscillation of meandering Bhagirathi on the alluvial flood plain of Bengal Basin, India; as controlled by the Palaeo-geomorphic architecture. Int J Geomat Geosci 5(4):564-572

60. Pal R, Biswas SS, Pramanik MK, Mondal B (2016) Bank vulnerability and avulsion modelling of the Bhagirathi-Hooghly river between Ajay and Jalangi confluences in lower Ganga plain. India Model Earth Syst Environ 2:65. https://doi.org/10.1007/ s40808-016-0125-7

61. Das TK, Halder SK, Gupta ID, Sen S (2014) River bank erosion induced human displacement and its consequences. Living Rev Landsc Res 8(3):5-17. https://doi.org/10.12942//rIr-2014-3

62. Debnath J, Das N, Ahmed I, Bhowmik M (2017) Channel migration and its impact on land use/ land cover using RS and GIS: a study on Khowai river of Tripura, North-East India. Egypt J Remote Sens Space Sci 20:197-210. https://doi.org/10.1016/j. ejrs.2017.01.009

63. Langbein WB, Leopold LB (1966) River meanders-theory of minimum variance. Geological survey professional paper 422$\mathrm{H}$, United States government printing office, Washington, $\mathrm{pp}$ 1-21. doi:https://doi.org/10.3133/pp422H 
64. Schumm SA (1963) Sinuosity of alluvial rivers in the Great Plains. Geol Soc Am Bull 74:1089-1100. https://doi.org/10.1130/00167606(1963)74[1089:SOAROT]2.0.CO;2

65. Mueller JE (1968) An introduction to the hydraulic and topographic sinuosity indexes. Ann Assoc Am Geogr 58(2):371-385. https://doi.org/10.1111/j.1467-8306.1968.tb00650.x
66. Williams GP (1986) River meanders and channel size. J Hydrol 88(1-2):147-164. https://doi.org/10.1016/0022-1694(86)90202-7

Publisher's Note Springer Nature remains neutral with regard to jurisdictional claims in published maps and institutional affiliations. 